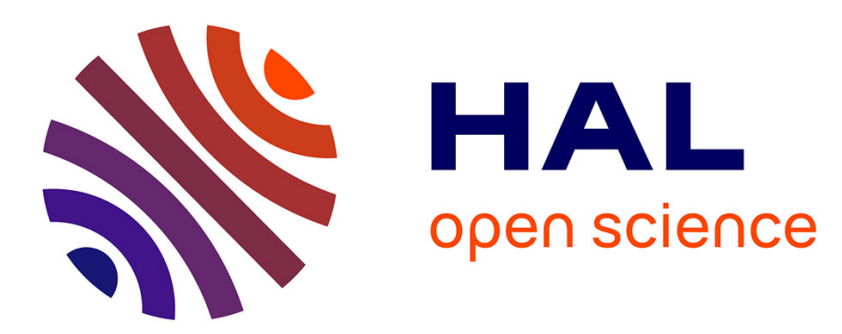

\title{
Gas-phase basicity of glycine, alanine, proline, serine, lysine, histidine and some of their peptides by the thermokinetic method
}

Guy Bouchoux, Jean-Yves Salpin

\section{- To cite this version:}

Guy Bouchoux, Jean-Yves Salpin. Gas-phase basicity of glycine, alanine, proline, serine, lysine, histidine and some of their peptides by the thermokinetic method. European Journal of Mass Spectrometry, 2003, 9 (4), pp.391-402. 10.1255/ejms.568 . hal-00068599

\section{HAL Id: hal-00068599 \\ https://hal.science/hal-00068599}

Submitted on 17 Oct 2018

HAL is a multi-disciplinary open access archive for the deposit and dissemination of scientific research documents, whether they are published or not. The documents may come from teaching and research institutions in France or abroad, or from public or private research centers.
L'archive ouverte pluridisciplinaire HAL, est destinée au dépôt et à la diffusion de documents scientifiques de niveau recherche, publiés ou non, émanant des établissements d'enseignement et de recherche français ou étrangers, des laboratoires publics ou privés. 


\title{
Gas phase basicity of glycine, alanine, proline,
} serine, lysine, histidine and some of their peptides by the thermokinetic method.

\author{
G. Bouchoux ${ }^{\mathrm{a}}$, J-Y. Salpin ${ }^{\mathrm{b}}$, \\ (a) Laboratoire des Mécanismes Réactionnels, UMR CNRS 7651, Ecole Polytechnique, \\ 91128 Palaiseau Cedex, France
}

(b) Laboratoire Analyse et Environnement, UMR 8587, Bâtiment des Sciences, Université d'Evry, boulevard F. Mitterrand, 91025 Evry cedex, France

Dedicated to Robert Flammang, a good friend and a fine scientist, on the occasion of his $60^{\text {th }}$ birthday.

\begin{abstract}
:
The thermokinetic method is applied to a set of six amino acids (glycine, alanine, proline, serine, lysine, histidine) and 30 of their di- and tri-peptides for which experimental proton transfer rate constants were available. The comparison between the presently determined gas phase basicities, GB's, of the aminoacids with values obtained from equilibrium constant determination is generally good (a mean deviation of $\sim 3 \mathrm{~kJ} / \mathrm{mol}$ is observed). Derived proton affinities values are discussed. The gas phase basicities of peptides provided by the present study correct several previously estimated values thus offering a more firm basis for structural discussion. Composite reaction efficiency curves indicate the existence, for several peptides, of at least two non interconverting populations of protonated forms.
\end{abstract}

Corresponding author:

Pr. Guy Bouchoux

DCMR. Ecole Polytechnique

91128 Palaiseau cedex

bouchoux@dcmr.polytechnique.fr

fax (33) 169333041 


\section{Introduction}

Protonation energetics of aminoacids and their polymers present obvious interest due to the important role played by proton transfer in biological processes. Moreover, the structure characterisation of these species by mass spectrometry invariably involves a protonation process. Thus the knowledge of the site of proton attachment as well as its energetic aspect is essential for the understanding of the reactions observed and the structural information obtained. For these reasons the intrinsic acid-bases properties of the 20 naturally occurring $\alpha$ amino acids and some of their peptides have attracted the interest since several decades. An excellent review on these questions appeared several years ago. ${ }^{1}$ Not long after, an extended compilation of evaluated gas phase basicity data expand and correct the previous estimates. ${ }^{2}$

Since this period, a new alternative method of determination of gas phase basicity appeared (the "thermokinetic method") ${ }^{3,4}$ and limitations on the validity of results obtained by the most commonly used method of determining thermochemical data: the "kinetic method", was emphasized. ${ }^{5}$ As a result, it was of interest to examine the presently available data with a new glance. In the present study we apply the 'thermokinetic method" to the proton transfer rate constant previously measured during FT-ICR experiments in order to derive new estimates for the gas phase basicities of a number of aminoacids (glycine, alanine, proline, serine, lysine, and histidine) and of some of their peptides.

\section{Results and discussion}

\section{Methods}

The gas phase basicity, $\mathrm{GB}(\mathrm{M})$, and the proton affinity, PA(M), of a given species $\mathrm{M}$, (i.e. the free energy and the enthalpy of the reaction $\mathrm{MH}^{+} \rightarrow \mathrm{M}+\mathrm{H}^{+}$) may be obtained by studying proton transfer reaction (1):

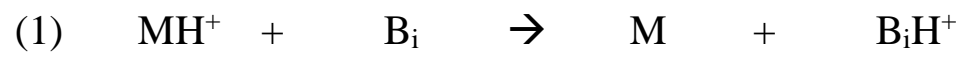

If reaction (1) is performed, for a sufficiently long time, in presence of gaseous $\mathrm{M}$ and $B_{i}$, an equilibrium may be attained from which the difference in gas phase basicity may be deduced according to $\mathrm{GB}(\mathrm{M})-\mathrm{GB}\left(\mathrm{B}_{\mathrm{i}}\right)=\Delta_{1} \mathrm{G}^{\circ}$. One limitation of this equilibrium method is the necessity of a correct pressure measurement for both the neutral $\mathrm{M}$ and $\mathrm{B}_{\mathrm{i}}$ in order to 
determine precisely the equilibrium constant. Obviously, this condition is not easily fulfilled with amino acids or, a fortiori, peptides which are compounds of low volatility. To circumvent this problem, two other approaches were used during the years. The simplest one is the "bracketing" method where the disappearance of $\mathrm{MH}^{+}$(or appearance of $\mathrm{B}_{\mathrm{i}} \mathrm{H}^{+}$) via reaction (1) is qualitatively appreciated in order to decide if it is an endergonic or an exergonic process: briefly, it is stated that if reaction (1) is "efficient", then $G B\left(B_{i}\right)>G B(M)$. The weakness of the bracketing method lies in the somewhat arbitrary definition of an efficient reaction. This arbitrariness is at the origin of unexpectedly large uncertainties on GB(M) (up to several tens of $\mathrm{kJ} / \mathrm{mol}$ as it will be shown below for the examined peptides). The second approach is the "kinetic method" which is based on the competitive dissociation of a protonated dimer $\mathrm{MHB}_{\mathrm{i}}^{+}$(into $\mathrm{MH}^{+}+\mathrm{B}_{\mathrm{i}}$ and $\mathrm{M}+\mathrm{B}_{\mathrm{i}} \mathrm{H}^{+}$) and the assumption that $\ln \left(\left[\mathrm{MH}^{+}\right] /\left[\mathrm{B}_{\mathrm{i}} \mathrm{H}^{+}\right]\right)=\left[\mathrm{GB}_{\mathrm{T}}(\mathrm{M})-\mathrm{GB}_{\mathrm{T}} *\left(\mathrm{~B}_{\mathrm{i}}\right)\right] / \mathrm{RT}^{*}$ (where $\mathrm{T}^{*}$ is an "effective" temperature). It should be also mentioned that $\left[\mathrm{GB}_{\mathrm{T}}(\mathrm{M})-\mathrm{GB}_{\mathrm{T} *}\left(\mathrm{~B}_{\mathrm{i}}\right)\right]$ may be equated to $\left[\mathrm{PA}_{298}(\mathrm{M})-\mathrm{PA}_{298}\left(\mathrm{~B}_{\mathrm{i}}\right)+\right.$ $\mathrm{T}^{*} \Delta \mathrm{S}^{\circ}$, where the entropy term $\Delta \mathrm{S}^{\circ}$ is equal to $\mathrm{S}^{\circ}\left(\mathrm{MH}^{+}\right)+\mathrm{S}^{\circ}\left(\mathrm{B}_{\mathrm{i}}\right)-\mathrm{S}^{\circ}(\mathrm{M})-\mathrm{S}^{\circ}\left(\mathrm{B}_{\mathrm{i}} \mathrm{H}^{+}\right)$(or $\Delta \mathrm{S}^{\circ}=$ $\Delta_{\mathrm{p}} \mathrm{S}^{\circ}(\mathrm{M})-\Delta_{\mathrm{p}} \mathrm{S}^{\circ}\left(\mathrm{B}_{\mathrm{i}}\right)$ if we define the "protonation entropy" ${ }_{\mathrm{p}} \mathrm{S}^{\circ}(\mathrm{X})$ by the difference $\left.\mathrm{S}^{\circ}\left(\mathrm{XH}^{+}\right)-\mathrm{S}^{\circ}(\mathrm{X})\right)$ if $\Delta \mathrm{PA}$ and $\Delta \mathrm{S}^{\circ}$ are considered temperature independent. In the earlier applications of the kinetic method, it was simply assumed that $\ln \left(\left[\mathrm{MH}^{+}\right] /\left[\mathrm{B}_{\mathrm{i}} \mathrm{H}^{+}\right]\right)=\left[\mathrm{GB}_{298}(\mathrm{M})-\right.$ $\left.\mathrm{GB}_{298}\left(\mathrm{~B}_{\mathrm{i}}\right)\right] / \mathrm{RT}^{*}$ or even $\ln \left(\left[\mathrm{MH}^{+}\right] /\left[\mathrm{B}_{\mathrm{i}} \mathrm{H}^{+}\right]\right)=\left[\mathrm{PA}_{298}(\mathrm{M})-\mathrm{PA}_{298}\left(\mathrm{~B}_{\mathrm{i}}\right)\right] / \mathrm{RT}^{*}$. Clearly these approximations are correct only if $\Delta \mathrm{S}^{\circ}=0$ and great care should be taken when considering the literature data that this condition is indeed fulfilled. Recently, the consideration of the complete relationship $\ln \left(\left[\mathrm{MH}^{+}\right] /\left[\mathrm{B}_{\mathrm{i}} \mathrm{H}^{+}\right]\right)=\left[\mathrm{PA}_{298}(\mathrm{M})-\mathrm{PA}_{298}(\mathrm{Bi})+\mathrm{T}^{*} \Delta \mathrm{S}^{\circ}\right] / \mathrm{RT}^{*}$ has been done in the so called "full entropy analysis" method in order to derive both $\mathrm{PA}_{298}(\mathrm{M})$ and $\Delta \mathrm{S}^{\circ}$. However, several studies ${ }^{5}$ lead to the conclusion that the $\Delta S^{\circ}$ term determined by the "full entropy analysis" method is not exactly the true difference in protonation entropies between $\mathrm{M}$ and $\mathrm{B}$, but only a part of it. Moreover, the participation of a reverse critical energy cannot be excluded for one or the other dissociation thus leading to a wrong estimate of $\mathrm{PA}_{298}(\mathrm{M})$.

The thermokinetic method of determination of gas phase basicity uses a correlation between the reaction efficiency, RE, and the standard free energy change of a series of proton transfer processes. ${ }^{3}$ For reaction (1) the expected correlation is expressed as:

$$
\mathrm{RE}=\mathrm{k}_{\mathrm{exp}} / \mathrm{k}_{\text {coll }}=\left[1+\exp \left(\left(\Delta_{1} \mathrm{G}^{\circ}+\Delta \mathrm{G}_{\mathrm{a}}^{\circ}\right) / \mathrm{RT}^{*}\right)\right]^{-1}
$$


where, $k_{\exp }$ and $k_{\text {coll }}$ are the experimental and collision rate coefficients, $\Delta_{1} G^{\circ}$ the Gibbs free energy change of reaction 1 (i.e. $\Delta_{1} G^{\circ}=G B(M)-G B\left(B_{i}\right)$ ) and $\Delta G_{a}{ }^{\circ}$ an empirical corrective term. GB(M) can thus be deduced by plotting the RE of reaction 1 , for a series of bases $B_{i}$ of known basicities, as a function of $\mathrm{GB}\left(\mathrm{B}_{\mathrm{i}}\right)$ and by fitting the data with a parametric sigmoid function of the type:

$$
\mathrm{RE}=\mathrm{a} /\left[1+\exp \left(\mathrm{b}\left(\mathrm{c}-\mathrm{GB}\left(\mathrm{B}_{\mathrm{i}}\right)\right)\right]\right.
$$

It has been empirically established that the corrective term $\Delta \mathrm{G}_{\mathrm{a}}{ }^{\circ}$ (which shifts the position of the onset) is closely related to the slope b of the sigmoid graph. ${ }^{3,4}$ In fact, $\Delta \mathrm{G}_{\mathrm{a}}{ }^{\circ} \sim$ 1/b and consequently GB(M) may be calculated according to:

$$
\mathrm{GB}(\mathrm{M})=\mathrm{c}-1 / \mathrm{b}
$$

Applications of this method to various situations ${ }^{4}$ has proven to correctly compare with results obtained by equilibrium constant determinations and to provide figures with an accuracy generally better than $5 \mathrm{~kJ} / \mathrm{mol}$. It was consequently of interest to apply the thermokinetic method to aminoacids and peptides, species not easily amenable to equilibrium experiments due to their low volatility. In the present work, the rate coefficients of the deprotonation reactions (1), involving $\mathrm{M}=$ glycine, alanine, proline, serine, lysine and histidine and 30 of their peptides, has been exploited. These quantities and the relevant reaction efficiencies have been previously determined by Cassady and coworkers from FTICR experiments. ${ }^{6-10}$ We use this rich set of data, together with the $G B\left(B_{i}\right)$ taken from the compilation by Hunter and $\mathrm{Lias}^{2}$, to calculate GB(M) by means of eq. (3) and (4). A nonlinear iterative least square procedure has been used to solve eq. (3) (Levenberg-Marquard algorithm implemented in the IGOR Pro package, Wavemetrics Inc). The values of the fitting parameters a-c and the corresponding standard deviations are given in Table 1. The resulting gas phase basicities $\mathrm{GB}(\mathrm{M})$ will be given and discussed in the following parts.

Table 1 


\section{Gas phase basicities of aminoacids}

Table 2 gathers the GB(M) values of the considered aminoacids originating from different sources: earlier determinations by the equilibrium and the bracketing methods, and the present data resulting from the use of the thermokinetic technique to experimental results of ref. 6-10.

\section{Table 2}

The first estimates of the gas phase basicity of amino acids were coming from the determination of proton transfer equilibrium constants, either by high pressure mass spectrometry $^{11}$ or ion cyclotron resonance mass spectrometry ${ }^{12}$. Moreover, the former experiments, conducted at variable temperature, allowed, for glycine, alanine and proline, the determination of their proton affinity and protonation entropy, $\Delta_{\mathrm{p}} \mathrm{S}^{\circ}(\mathrm{M})=\mathrm{S}^{\circ}\left(\mathrm{MH}^{+}\right)-\mathrm{S}^{\circ}(\mathrm{M})$, from relevant van t'Hoff plots.

Proton transfer reaction bracketing involving the six aminoacids considered have been examined by several authors ${ }^{6-10,13,14}$. As recalled above, the uncertainty attached with the gas phase basicity estimate may be considerable by this method if the reaction efficiency is defined only qualitatively. This may be illustrated by the results obtained by this procedure using the data of references 6-10, 13 and 14. The range of values indicated in Table 2 under the heading "Bracketing" may be as large as $50 \mathrm{~kJ} / \mathrm{mol}$.

Finally, the last column in Table 2 contains the results of the present quantitative use of the bracketing experiments by way of the "thermokinetic method". Figure 1a-e illustrates the quality of the correlations. The curve fitting parameters presented in Table 1 exhibit only limited deviations and the precision on the corresponding estimate of the GB values are close to the usual accuracy on such type of measurements ${ }^{2,3,4}$. This is illustrated by the figures given in the last column of Table 2. In fact, the less satisfactorily correlation is obtained for lysine and histidine (Figure 1e) since only a limited number of points delimits the ascending part of the sigmoid curve. This leads to larger uncertainties for these measurements (7.5 and 5.4 $\mathrm{kJ} / \mathrm{mol}$ respectively, Table 2 ).

\section{Figure 1}


One may underline that the reaction rate constant measurements by Cassady and coworkers $^{6-10}$ were obtained after cooling the ions in the FT-ICR cell by admitting a pulse of argon during a $0.5 \mathrm{~s}$ period. By contrast, $\mathrm{Wu}$ and Lebrilla ${ }^{14}$ reported rate constant values obtained without collisional cooling for proton transfer reactions involving glycine, alanine, valine and some of their oligomers. A comparison between the two type of results is illustrated in Figure 1a for glycine. It appears that the use of the non thermalized reactants results in a shift of the onset to higher value and to a significant decrease of the slope of the sigmoid curve thus producing larger uncertainties on the derived GB values (both are increased by ca. $10 \mathrm{~kJ} / \mathrm{mol}$ in the present case). These changes are not unexpected since the sampling of vibrationally excited reactant ions is known to produce a slow down effect on the bimolecular reaction rate. Thus, an efficient thermalization of the reactants before reaction rate measurement is essential when quantitative reaction efficiencies are needed. This prompted us to exclusively use the data presented by Cassady et al. ${ }^{6-10}$ during the completion of the present work.

From examination of Table 2 it immediately appears that, for glycine, alanine and proline, the gas phase basicities obtained by the present thermokinetic treatment and by the equilibrium method agree nicely when considering the Mautner ${ }^{11}$ results. The mean deviation is $\sim 3 \mathrm{~kJ} / \mathrm{mol}$ even when including the, probably too high, value of $877.9 \mathrm{~kJ} / \mathrm{mol}$ obtained for alanine $^{11}$. The comparison between our thermokinetic GB(M) values and those deduced from the Locke ${ }^{12}$ experiments demonstrates a systematic underestimate, with a mean deviation of $7.7 \pm 4.6 \mathrm{~kJ} / \mathrm{mol}$. Harrison ${ }^{1}$ carefully discussed the uncertainty attached with the estimate of the neutral pressure in the Locke ${ }^{12}$ experiments and suggests that the derived GB values may have some, undetermined, errors. When a comparison is possible between the gas phase basicities obtained by the two aforementioned equilibrium techniques, it indeed appears that the Locke ${ }^{12}$ estimates are always situated above the Mautner ${ }^{11}$ values. This comparison, which include measurements for glycine, alanine, valine, leucine, phenylalanine and proline, leads to a mean deviation of $8.3 \pm 3.7 \mathrm{~kJ} / \mathrm{mol}$ between the two sets of data. This is clearly comparable to the shift of $7.7 \pm 4.6 \mathrm{~kJ} / \mathrm{mol}$ we observe here, and this give weight to the proposal that the gas phase basicities obtained by the thermokinetic method for the presently studied aminoacids are essentially correct. 


\section{Proton affinities of aminoacids}

Table 3 contains the relevant proton affinity and protonation entropy, $\Delta_{\mathrm{p}} \mathrm{S}^{\circ}(\mathrm{M})=$ $\mathrm{S}^{\circ}\left(\mathrm{MH}^{+}\right)-\mathrm{S}^{\circ}(\mathrm{M})$, of the studied aminoacids.

\section{Table 3}

A number of amino acid proton affinities have been derived using the kinetic method. ${ }^{15-21}$ In its simplest form, this procedure consists in considering that the proton affinity, $\mathrm{PA}(\mathrm{M})$, is defined by the intercept of the $\ln \left(\mathrm{MH}^{+}\right) /\left(\mathrm{B}_{\mathrm{i}} \mathrm{H}^{+}\right)$versus $\mathrm{PA}\left(\mathrm{B}_{\mathrm{i}}\right)$ line with the $\mathrm{x}$ axis. Values obtained by this way ${ }^{15,16,18}$ are reported in Table 3, including the correction due to the Hunter and Lias $^{2}$ assignment of the proton affinities of the various reference bases. A general examination of these data demonstrates a spread of values of 4 to $28 \mathrm{~kJ} / \mathrm{mol}$. This situation is not unexpected for systems subjected to large entropy effect such as lysine and histidine. Accordingly, as recalled in the previous part, the $\mathrm{x}$ intercept would give an apparent proton affinity given by $\mathrm{PA}_{298}(\mathrm{M})+\mathrm{T} \Delta_{\mathrm{p}} \mathrm{S}^{\circ}$. Consequently, if $\Delta_{\mathrm{p}} \mathrm{S}^{\circ}$ is not negligible, the apparent proton affinity is different from the true $\mathrm{PA}_{298}(\mathrm{M})$. Moreover, this apparent proton affinity should be also dependent on the experimental conditions, as reflected by the "effective temperature" T. The determination of a "true" proton affinity by explicitly considering the entropy effect in the kinetic method (the "full entropy analysis"), has been done for alanine ${ }^{21}$, proline ${ }^{19,20}$, lysine ${ }^{17}$ and histidine ${ }^{17}$. The corresponding values are indicated into brackets in Table 3, note that they are obtained by reexamination of the original data and adjusted to the Hunter\&Lias compilation ${ }^{2}$.

Finally the three PA values obtained for glycine, alanine and proline by a van't Hoff plot originating from variable temperature equilibrium constant determinations are also presented in Table 3.

Protonation entropies $\Delta_{\mathrm{p}} \mathrm{S}^{\circ}(\mathrm{M})=\mathrm{S}^{\circ}\left(\mathrm{MH}^{+}\right)-\mathrm{S}^{\circ}(\mathrm{M})$ are indicated in the last column of Table 3. In their compilation, Hunter\&Lias ${ }^{2}$ generally assumed that $\Delta_{\mathrm{p}} \mathrm{S}^{\circ}=-5 \mathrm{~J}_{\mathrm{mol}}{ }^{-1} \cdot \mathrm{K}^{-1}$, for $\alpha$-amino acids not bearing a basic site in their side chain. In fact this value has been assigned by comparison with methylamine for which $\Delta_{\mathrm{p}} \mathrm{S}^{\circ}=-7 \mathrm{~J} \cdot \mathrm{mol}^{-1} \cdot \mathrm{K}^{-1}$. The expectation of an entropy loss during protonation of simple $\alpha$-amino acids should not be surprising if one 
recalls that the protonated forms enjoy an intramolecular hydrogen bond between the amino group and the oxygen of the carbonyl. However, the three $\Delta_{\mathrm{p}} \mathrm{S}^{\circ}$ values experimentally obtained for glycine, alanine and proline, from a van't Hoff plot using the protonation equilibrium constants at variable temperature ${ }^{11}$, are positive, though relatively small (Table 3). By contrast, for $\alpha$-amino acids bearing a basic site in their side chain, a more significant entropy loss is expected upon protonation. This may particularly concern lysine and histidine and, to a lesser extend, serine. By using the full entropy analysis method, "apparent" $\Delta_{\mathrm{p}} \mathrm{S}^{\circ}$ values of -17 and $-42 \mathrm{~J} \mathrm{~mol}^{-1} \cdot \mathrm{K}^{-1}$ have been determined for histidine and lysine respectively ${ }^{16}$. These values compare hardly with that determined by variable temperature equilibrium constant measurements for 1,3- and 1,5-diamines, i.e. -50 and $-70 \mathrm{~J} \cdot \mathrm{mol}^{-1} \cdot \mathrm{K}^{-1}$ respectively. This discrepancy is in line with the general observation that the "apparent" entropy term determined by the kinetic method is not equal to, and may be considerably less than, the $\Delta_{\mathrm{p}} \mathrm{S}^{\circ}$ derived from equilibrium constant determination.

The proton affinity values indicated in bold in Table 3 are estimated using the relationship:

(5) $\mathrm{PA}_{298}(\mathrm{M})=\mathrm{GB}_{298}(\mathrm{M})+298\left[\mathrm{~S}_{298}{ }^{\circ}\left(\mathrm{H}^{+}\right)-\Delta_{\mathrm{p}} \mathrm{S}^{\circ}(\mathrm{M})\right]$ with $\mathrm{S}_{298}{ }^{\circ}\left(\mathrm{H}^{+}\right)=108.8 \mathrm{~J} \cdot \mathrm{mol}^{-1} \cdot \mathrm{K}^{-1}$.

where $\mathrm{GB}_{298}(\mathrm{M})$ is assigned the thermokinetic value (Table 2) and $\Delta_{\mathrm{p}} \mathrm{S}^{\circ}(\mathrm{M})$ the value indicated in the relevant line of the last column of Table 3. These thermokinetic proton affinities agree generally correctly (i.e. with a mean deviation less than $5 \mathrm{~kJ} / \mathrm{mol}$ ) with the values obtained by the equilibrium method or the full entropy analysis method.

Gas-phase basicities of small peptides

The thermokinetic procedure has been applied to the determination of the gas phase basicities of several peptides combining the aminoacids studied above. The GB(M) values deduced from the thermokinetic treatment are gathered in Tables 4 and 5.

Table 4

Table 5 
Considering first the dipeptides, the thermokinetic curve fitting (illustrated by Figure 2) lead to GB values with an accuracy (mean standard deviation) of $\sim 3 \mathrm{~kJ} / \mathrm{mol}$.

Figure 2

Comparison with other estimates is uneasy since the presently tabulated values ${ }^{2}$ essentially come from a qualitative use of the bracketing method using also the experimental results of ref. 7,9 and 10! The two exceptions concern GlyGly and AlaAla for which GB estimates based on the use of the kinetic method without considering entropy effect are available $22 \mathrm{a}, 22 \mathrm{~b}$. Despite this situation, considering the large use of the Hunter and Lias compendium $^{2}$, we nevertheless indicate their estimates, and the corresponding uncertainty range, in the third column of Table 4. The difference between the two set of data is not dramatically large, sizeable shifts are observed essentially for GlyHis, HisGly and LysGly. For the two former cases, the reason is straightforward after examination of Figure $2 \mathrm{~g}$. The two sets of points associated with the reaction efficiencies of GlyHis and HisGly are superimposable pointing obviously to identical GB values for both peptides, however the reaction efficiency demonstrates an evident footing in the low basicity region. A curve fitting by two functions of the type given by eq. 3 (dotted line in Figure 2g) indicates that this low GB component participates to 40\%, with indeed a GB value close to $955 \mathrm{~kJ} / \mathrm{mol}$. Since, in the original work ${ }^{10}$, the onset has been defined by a $10 \%$ efficiency break, it follows that it has been assigned a GB value taking exclusively into account the low efficiency part of the curve. The fitting of the major ( 60\%) component leads however to a basicity of GlyHis and HisGly higher by $20 \mathrm{~kJ} / \mathrm{mol}$. In the case of LysGly, the discrepancy between the thermokinetic result and the Hunter\&Lias value ${ }^{2}$ is due to the fact that the latter is wrong because of an error in the Table 2 of ref. 10. Accordingly, the penultimate reference base in this Table is certainly not N,N-Dimethylpropylamine but rather N,N-Dimethyl-1,3-Diaminopropane which corresponds to the correct GB value of $975.3 \mathrm{~kJ} / \mathrm{mol}$ (not 935 !).

\section{Table 5}

Figure 3

The gas phase basicity of fifteen other peptides, mainly tripeptides, has been also considered. Table 5 gathers our results and the GB values evaluated by Hunter and Lias². Again, the latter are coming from bracketing estimates ${ }^{6,9,10,14 a}$ or from the application of the 
kinetic method to competitive dissociations of proton bound dimers ${ }^{22}$. For triglycine, the large number of points provided by Zhang et al. in their original paper allows a clear curve fitting (Figure 3a). Using eq. 3 and 4, we derive a value of $\mathrm{GB}\left(\mathrm{Gly}_{3}\right)=903.9 \pm 3.4 \mathrm{~kJ} / \mathrm{mol}$ which compares hardly with the Hunter\&Lias value of $916.8 \mathrm{~kJ} / \mathrm{mol}$. In fact the latter value is obtained using $\mathrm{GB}_{298}(\mathrm{M})=\mathrm{PA}_{298}(\mathrm{M})-298\left[\mathrm{~S}_{298}{ }^{\circ}\left(\mathrm{H}^{+}\right)-\Delta_{\mathrm{p}} \mathrm{S}^{\circ}(\mathrm{M})\right]$, the terms $\mathrm{PA}_{298}(\mathrm{M})$ and $\Delta_{\mathrm{p}} \mathrm{S}^{\circ}(\mathrm{M})$ being obtained by the full entropy analysis kinetic method. Since this method generally provides only a lower limit of the absolute value of the entropy term $\Delta_{\mathrm{p}} \mathrm{S}^{\circ}(\mathrm{M})$, the $\mathrm{GB}_{298}(\mathrm{M})$ value of $916.8 \mathrm{~kJ} / \mathrm{mol}$ is probably overestimated. A similar remark applies to GlyGlyAla and AlaGlyGly which present GB values close to that of GlyGlyGly. Again, the thermokinetic method provides values clearly less than that given by Hunter\&Lias which originate also from the use of the kinetic method ${ }^{22 b}$. Finally, the close basicities of the three isomers GlyGlyAla, GlyAlaGly and AlaGlyGly is noteworthy (Figure 3b). The deprotonation efficiencies of the conjugated acids of GlyGlyPro, GlyProGly and ProGlyGly are clearly the sum of two contributions (Figures 3c-e). Only the low GB components have been identified in the original paper by Ewing et al. ${ }^{9}$, the 10\% efficiency limit corresponds to the GB estimates given in the H\&L tabulation (Table 5$)^{2}$. The second component corresponds to basicity higher by $\sim 70 \mathrm{~kJ} / \mathrm{mol}$ for GlyGlyPro and GlyProGly, and by $\sim 40 \mathrm{~kJ} / \mathrm{mol}$ for ProGlyGly. A comparable situation is encountered for GlyHisGly (Figure 3f), the low GB component represent $40 \%$ in that case and the difference in basicity is $\sim 30 \mathrm{~kJ} / \mathrm{mol}$. By contrast the efficiency curves of the two isomeric peptides GlyGlyHis and HisGlyGly are monocomponent and superimposable, it corresponds to a common gas phase basicity value of $976 \mathrm{~kJ} / \mathrm{mol}$, i.e. slightly lower than the most basic site of GlyHisGly. Figure 3g illustrates the deprotonation efficiencies of the three isomers GlyGlyLys, GlyLysGly and LysGlyGly. We note that the tabulated GB values of HisGlyGly, GlyGlyLys and LysGlyGly are false for the same reason as that given above for LysGly. Finally, the gas phase basicities of tetra-, pentaand hexa-glycine have been determined. The efficiency curves (Figures 3h) present an undecided starting point which may dissimulate a small participation of low basicity components we don't try to extract. Our results demonstrate an increase in basicity when passing from (Gly) 4 to (Gly)6, as expected, but as not indicated for (Gly) $)_{5}$ in ref. 2 since Hunter and Lias retain a "full entropy" kinetic method value ${ }^{22 c}$ for (Gly)4, and an averaged value combining standard kinetic method ${ }^{22 a, 22 b}$ and bracketing data ${ }^{6,14 a}$ for (Gly) $)_{5}$ and (Gly) 6 (thus explaining the deviation of $26 \mathrm{~kJ} / \mathrm{mol}$ and $17 \mathrm{~kJ} / \mathrm{mol}$ respectively, indicated in Table 5). 


\section{Structural considerations}

A long standing question is how is related the basicity of a peptide with the basicity of the corresponding individual aminoacids. It should be first recalled that the thermochemicallly favoured site of protonation of $\alpha$-aminoacids is generally the amino group, the exceptions are arginine, histidine, lysine and probably tryptophane where the side chain bears a second, more basic site. The second important structural characteristic of the protonation of $\alpha$-aminoacids is the stabilisation of the protonated form by intramolecular hydrogen bonding. For simple aminoacids this favourable interaction occurs with the oxygen atom of the carbonyl group. When protonation is possible on the side chain, the intramolecular hydrogen bond is established with the nitrogen atom of the $\alpha$-amino group.

Intramolecular interactions play increasing role in peptides as indicated by several studies involving molecular orbital calculations on glycylglycine ${ }^{6,14 a, 24}$. The most stable protonated form corresponds to protonation at the terminal amino group because a strong intramolecular hydrogen bond is established between the protonated terminal amino group and the neighbouring carbonyl amide. A second hydrogen bond is simultaneously possible between another hydrogen of the protonated terminal amino group and the carbonyl acid. Protonation at the amide nitrogen atom is predicted to be $\sim 70 \mathrm{~kJ} / \mathrm{mol}$ higher ${ }^{24}$. The gas phase basicities of polyglycines continue to increase as additional residues are added. However, as noted previously ${ }^{6,14 a, 22 b}$, it progressively becomes less important when the size of the peptide increases and illustrated by Figure 4.

Figure 4

For the dipeptides GlyY, with Y=Gly, Ala, Ser and Pro, the increase in basicity (from 26 to $56 \mathrm{~kJ} / \mathrm{mol}$ ), with respect to $\mathrm{GB}(\mathrm{Gly})$, is linearly dependent upon $\mathrm{GB}(\mathrm{Y})$ with a slope of $\sim 0.7$. In the hypothesis of protonation on the terminal amino group this is in agreement with a strengthening of the internal hydrogen bond due to a better donating effect of the amide nitrogen atom which increases the electron density on the oxygen atom. In the same line, the basicities of the peptides XGly are increased, with respect to Gly, by a constant amount of ca. $26 \mathrm{~kJ} / \mathrm{mol}$ for $\mathrm{X}=\mathrm{Gly}$, Ala, Ser and Pro. Proline, as a secondary amine presents a more efficient basic site (its GB is $45 \mathrm{~kJ} / \mathrm{mol}$ higher than glycine, Table 1), and acts as a better donating group when involved in an amide function. The first effect is clearly evidenced by 
the increases in GB from GlyGly to ProGly (49 kJ/mol) and from GlyPro to ProPro (47 $\mathrm{kJ} / \mathrm{mol}$ ). The mesomeric effect is illustrated by the increases in GB from GlyGly to GlyPro (30 kJ/mol) and from ProGly to ProPro $(29 \mathrm{~kJ} / \mathrm{mol})$. Obviously ProPro is the most basic dipeptide in this series ${ }^{9}$.

The most favourable protonation site of lysine and histidine are nitrogen atoms located in their side chain. As recalled before, the formation of an intramolecular hydrogen bond with the $\alpha$-amino group is at the origin of a significant increase of basicity of these two molecules. The results indicated in Tables 2 and 3 show that lysine and histidine have comparable gas phase basicities $(941 \mathrm{~kJ} / \mathrm{mol})$, but slightly different proton affinities. Chelation of the proton results in a better enthalpy gain, but a less favourable entropy effect, for lysine than for histidine. Protonation of the dipeptides containing either lysine or histidine is expected to also occur preferentially on the extra nitrogen atoms. As a first consequence, it is expected that the localisation at the $\mathrm{N}$ or $\mathrm{C}$ terminal position would have limited effect on the GB values. This is indeed confirmed for GlyHis and HisGly but not for GlyLys and LysGly. In this latter case, a difference of $15 \mathrm{~kJ} / \mathrm{mol}$ is quoted in Table 4, however the experimental points in Figure $2 \mathrm{~h}$ (GlyLys) cover a significantly larger GB range than in Figure 2i (LysGly) and this renders the comparison uneasy. Significantly enough, the LysGly fitting curves (Figure 2i) matches closely the high basicity component of the GlyHis and HisGly curves (Figure 2g) pointing to a comparable GB of $\sim 975 \mathrm{~kJ} / \mathrm{mol}$. This corresponds to an increase in gas phase basicity of ca. 30-35 kJ/mol with respect to lysine or histidine. It has been suggested that most of the stabilization of the protonated dipeptides containing lysine or histidine is due to an intramolecular hydrogen bonding between the protonated nitrogen atom of the side chain and the terminal amine ${ }^{10}$. Further favourable interactions are also expected with the carbonyl oxygens. The observed increase in basicity is of course compatible with this proposal, however, a complete discussion of these observations will be possible only when the nature and the number of intramolecular interactions stabilizing these protonated dipeptides will be more deeply documented, .

Comparable comments may be done about the protonation of the studied tripeptides. One remark concerns the two series containing the "basic" aminoacids histidine and lysine. In both cases the peptide bearing His or Lys in the middle position present a peculiar behaviour. The lowest basicity of GlyLysGly with respect to GlyGlyLys and LysGlyGly, 20 kJ/mol, may possibly illustrate steric hindrance to the protonation of the side chain of the central 
lysine aminoacid. For GlyHisGly, the minor (42\%) component to the reaction efficiency curve (Figure 3f) corresponds also to a decrease in basicity of $20 \mathrm{~kJ} / \mathrm{mol}$ with respect to HisGly and GlyGlyHis, but, by contrast, the major component is associated with a $\sim 10 \mathrm{~kJ} / \mathrm{mol}$ increase in basicity. Again, a complete discussion of these observation necessitates a larger knowledge of the possible protonation sites and the associated stabilization by intramolecular hydrogen bonding. As a corollary, an estimate of the entropy losses corresponding to the latter must be also considered when comparing basicities. These informations would be also useful in the identification of the two different populations of non interconverting $\mathrm{MH}^{+}$ion structures which appear to be sampled in several cases namely GlyHis, HisGly, GlyGlyPro, GlyProGly, ProGlyGly and GlyHisGly.

\section{Conclusion}

The thermokinetic method, which provides gas phase basicities from fitting reaction efficiencies of a set of proton transfer reactions, appears to be applicable to polydentate bases such as amino acids and peptides. The present study indicates that the precision obtained on the GB values may be comparable to that associated with the equilibrium method. The advantage of the thermokinetic method, however, is that it does not need the presence of gaseous neutral base during the experiments. Non volatile bioorganic molecules are consequently the target of choice for this kind of treatment, as illustrated here.

Several GB values tabulated in ref. 2 should be revised, it mainly concerns LysGly, HisGlyGly, GlyGlyLys and LysGlyGly which are erroneous by $30 \mathrm{~kJ} / \mathrm{mol}$. For proline, lysine and histidine shifts of ca. $10 \mathrm{~kJ} / \mathrm{mol}$ are observed between our GB values (Table 2) and ref. 2, even if this difference is close to the summed error domains of both sources this point should be controlled.

The observation, in several cases, of composite reaction efficiency curves may indicate the existence of several non interconverting $\mathrm{MH}^{+}$species, an information of interest when discussing protonation sites and relevant structural aspects of protonated peptides. Further experiments are obviously needed to confirm these observations. 


\section{References}

1. A.G. Harrison, The Gas-Phase Basicities and Proton Affinities of Amino Acids and Peptides. Mass Spectrom. Rev. 16, 201-217 (1997).

2. E.P. Hunter, S.G. Lias, Evaluated Gas Phase Basicities and Proton Affinities of Molecules: An Update. J. Phys. Chem. Ref. Data 27, 413-656 (1998).

3. G. Bouchoux, J-Y. Salpin, D.Leblanc, A relationship between the kinetics and thermochemistry of proton transfer reactions in the gas phase. Int. J. Mass Spectrom. Ion Processes 153, 37-48 (1996).

4. a) G. Bouchoux, J-Y. Salpin, Thermokinetic Determination of Gas-Phase Basicities. Application to Ketene, Methylketene, and Formaldimine. J. Phys. Chem. 110, 1655516560 (1996).

b) G. Bouchoux, J-Y. Salpin, Gas-Phase Basicity and Heat of Formation of Sulfine $\mathrm{CH}_{2}=\mathrm{S}=\mathrm{O}$. J. Am. Chem. Soc. 118, 6516-6517 (1996).

c) M. Witt, H-F. Grützmacher, The gas phase basicity and proton affinity of propionamide: a comparison of methods. Int. J. Mass Spectrom. Ion Processes 164, 93106 (1997).

d) A. Ricci, M. Rosi, Gas-Phase Chemistry of $\mathrm{NH}_{x} \mathrm{Cl}_{y}{ }^{+}$. 1. Structure, Stability, and Reactivity of Protonated Monochloramin. J. Phys. Chem. A 102, 10189-10194 (1998).

e) B.K. Decker, N.G. Adams, L.M Babcock, Gas-phase reactivity of $\mathrm{HS}_{2} \mathrm{H}^{+\cdot}$ and $\mathrm{S}_{2}{ }^{+\cdot}$ : an investigation of the gas basicity and proton affinity of $\mathrm{HS}_{2} \cdot$ Int. J. Mass Spectrom. 185, 727-743 (1999).

f) G. Bouchoux, J-Y. Salpin, Re-evaluated gas phase basicity and proton affinity data from the thermokinetic method Rapid. Commun. Mass Spectrom. 13, 932-936 (1999).

g) M. Mormann, J-Y. Salpin, D. Kuck, The gas-phase basicities of 6-methylfulvene and 6,6-dimethylfulvene as determined by the thermokinetic method. Eur. Mass Spectrom. 5, 441-447 (1999).

h) F. Bernardi, F. Cacace, G. Occhiucci, A. Ricci, I. Rossi, Protonated Cyanogen Fluoride. Structure, Stability, and Reactivity of (FCN)H ${ }^{+}$Ions. J. Phys. Chem. A 104 , 5545-5550 (2000).

i) A. Ricci, M. Rosi, Gas Phase Chemistry of $\mathrm{NH}_{x} \mathrm{Cl}_{y}{ }^{+}$Ions. II. Structure, Stability and Reactivity of Protonated Dichloramine. J. Phys. Chem. A 104 , 5617-5624 (2000). 
j) M. Mormann, S. Bashir, P. Derrick, D. Kuck, Gas-phase basicities of the isomeric dihydroxybenzoic acids and gas-phase acidities of their radical cations. J. Am. Soc. Mass Spectrom. 11, 544-552 (2000).

k) G. Bouchoux, D. Leblanc, Gas-phase basicity of formaldehyde by the thermokinetic method. Eur. J. Mass Spectrom. 6, 109-112 (2000).

l) G. Bouchoux, B. Gaudin, D. Leblanc, M. Yáñez, O. Mó, Is ionized cyclopropylamine cyclic? Int. J. Mass Spectrom. 199, 59-69 (2000).

m) G. Bouchoux, D. Leblanc, M. Sablier, Determination of ionization energies by the thermokinetic method. Int. J. Mass Spectrom. 210/211, 189-201 (2001).

n) G. Bouchoux, J. Chamot-Rooke, D. Leblanc, P. Mourgues, M. Sablier, Proton Affinity and Heat of Formation of Vinyloxy $\left[\mathrm{CH}_{2} \mathrm{CHO}\right]$ and Acetonyl $\left[\mathrm{CH}_{2} \mathrm{COCH}_{3}\right]$. Radicals. ChemPhysChem 1, 235-241 (2001).

o) G. Bouchoux, F. Caunan, D. Leblanc, M.T. Nguyen, J-Y. Salpin, Protonation Thermochemistry of Ethyl Halides. ChemPhysChem 1, 604-610 (2001).

p) J.R. Brown, P. Schwertfeger, D. Schröder, H. Schwarz, Experimental and theoretical studies of diatomic gold halides. J. Am. Soc. Mass Spectrom. 13, 485-492 (2002).

q) G. Bouchoux, J-Y. Salpin, Cyclopentenyl Cation: its thermochemistry and its characterized formation from $\mathrm{C}_{6} \mathrm{H}_{10}{ }^{+}$. species. Chem. Phys Lett. 366, 510-519 (2002).

r) E. Baciocchi, M. Bietti, B. Chiavarino, M.E. Crestoni, S. Fornarini, The deprotonation of benzyl alcohol radical cations: A mechanistic dichotomy in the gas phase as in solution. Chem. Eur. J. 8, 532-537 (2002).

5. a) P.B. Armentrout, Is the kinetic method a thermodynamic method? J. Mass Spectrom. 34, 74-78 (1999).

b) P.B. Armentrout, Entropy measurements and the kinetic method: a statistically meaningful approach. J. Am. Soc. Mass Spectrom. 11, 371-379 (2000).

c) K.M. Ervin, Microcanonical analysis of the kinetic method. The meaning of the "apparent entropy", J. Am. Soc. Mass Spectrom. 13, 435-452 (2002).

d) J. Laskin, J.H. Futrell, The Theoretical Basis of the Kinetic Method from the Point of View of Finite Heat Bath Theory. J. Phys. Chem. A 104, 8829-8837 (2000).

e) J.J. Hache, J. Laskin, J.H.Futrell, Relative Proton Affinities from Kinetic Energy Release Distributions for Dissociation of Proton-Bound Dimers. J. Phys. Chem. A 106, 12051-12057 (2002). 
f) J. Cao, C. Aubry, J.L. Holmes, Proton Affinities of Simple Amines; Entropies and Enthalpies of Activation and Their Effect on the Kinetic Method for Evaluating Proton Affinities. J. Phys. Chem. A 104,10045-10052 (2000).

g) J. Cao, J.L. Holmes, The proton affinities of amin-alkanes. A test case for the kinetic method. Int. J. Mass Spectrom. 195/196, 525-532 (2000).

h) N. Morlender-Vais, J.L.Holmes, Proton affinities of two weakly bidentate molecules: 1,2-dimethoxyethane and methoxyacetone. Int. J. Mass Spectrom. 210/211,147-152 (2001).

i) G. Bouchoux, F. Djazi, F. Gaillard, D. Vierezet, Application of the kinetic method to bifunctional bases: MIKE and CID-MIKE test cases. Int. J. Mass Spectrom., in press.

j) G. Bouchoux, D-A. Buisson, S. Bourcier, M. Sablier, Application of the kinetic method to bifunctional basesESI tandem quadrupole experiments. Int. J. Mass Spectrom., in press.

6. a) K. Zhang, D.M. Zimmerman, A. Chung-Philips, C.J. Cassady, Experimental and ab initio studies of the gas-phase basicities of polyglycines. J. Am. Chem. Soc. 115, 1081210822 (1993).

b) K. Zhang, C.J. Cassady, A. Chung-Philips, Ab Initio Studies of Neutral and Protonated Triglycines: Comparison of Calculated and Experimental Gas-Phase Basicity. J. Am. Chem. Soc. 116, 11512-11521 (1994).

7. J.W. McKiernan, C.E.A. Beltrame, C.J. Cassady, Gas-phase basicities of serine and dipeptides of serine and glycine. J. Am. Soc. Mass Spectrom. 5, 718-723 (1994).

8. C.J. Cassady, S.R. Carr, K. Zhang, A. Chung-Philips, Experimental and Ab Initio Studies on Protonations of Alanine and Small Peptides of Alanine and Glycine. J. Org. Chem. 60, 1704 (1995).

9. N.P. Ewing, X. Zhang, C.J. Cassady, Determination of the Gas-Phase Basicities of Proline and its Di- and Tripeptides with Glycine: The Enhanced Basicity of Prolylproline. J. Mass Spectrom. 31, 1345-1350 (1996).

10. S.R. Carr, C.J. Cassady, Gas-Phase Basicities of Histidine and Lysine and their Selected Di- and Tripeptides. J. Am. Soc. Mass Spectrom. 7, 1203-1210 (1996).

11. M. Mautner, E.P. Hunter, F.H. Field, Ion thermochemistry of low-volatility compounds in the gas phase. 1. Intrinsic basicities of alpha-amino acids. J. Am. Chem. Soc. 101, 686689 (1979). 
12 a) M.J. Locke, R.L. Hunter, R.T. McIver Jr., Experimental determination of the acidity and basicity of glycine in the gas phase. J. Am. Chem. Soc. 101, 272-273 (1979).

b) M.J. Locke, Studies of low volatility compounds by ion cyclotron resonace mass spectrometry. Ph D thesis. University of California (1981).

c) M.J. Locke, R.T. McIver Jr., Effect of solvation on the acid/base properties of glycine. J. Am. Chem. Soc. 105, 4226-4232 (1983).

13. a) G.S. Gorman, J.P. Speir, C.A.Turner, I.J. Amster, Proton affinities of the 20 common .alpha.-amino acids. J. Am. Chem.Soc.114, 3986-3988 (1992).

b) G.S. Gorman, I.J. Amster, Gas-phase basicity measurements of dipeptides that contain valine. J. Am. Chem. Soc. 115, 5729-5735 (1993).

c) G.S. Gorman, I.J. Amster, Kinetic and Thermodynamic Considerations of the Bracketing Method: Entropy-Driven Proton-Transfer Reactions in a Fourier Transform Mass Spectrometer. Org. Mass Spectrom. 28, 1602-1610 (1993).

14. a) J.Wu, .CB. Lebrilla, Gas-phase basicities and sites of protonation of glycine oligomers (Glyn; n = 1-5). J. Am. Chem. Soc. 115, 3270-3275 (1993).

b) J.Wu, C.B. Lebrilla, Intrinsic Basicity of Oligomeric Peptides that Contain Glycine, Alanine, and Valine--The Effects of the Alkyl Side Chain on Proton Transfer Reactions. J. Am. Soc. Mass Spectrom. 6, 91-101 (1995).

15. X. Li, A.G. Harrison, A kinetic Approach to the Proton Affinities of Amine Bases. Org. Mass Spectrom. 28, 366-371 (1993).

16. G. Bojesen, T. Breindahl, On the proton affinity of some $\alpha$-amino acids and the theory of the kinetic method. J Chem. Soc. Perkin Trans 2, 1029 (1994).

17. Z. Wu, C.J. Fenselau, Gas-Phase Basicities and Proton Affinities of Lysine and Histidine Measured From the Dissociation of Proton Bound Dimers. Rapid Commun. Mass Spectrom. 8,777-780 (1994).

18. C. Afonso, F. Modeste, P. Breton, F. Fournier, J-C. Tabet, Proton affinity of the commonly occuring L-amino acids by using electrospray ionization-ion trap mass spectrometry. Eur. J Mass Spectrom. 6, 443-449 (2000).

19. S.P. Mirza, S.Prabhar, M. Vairamani, Estimation of proton affinity of proline and tryptophan under electrospray ionization conditions using the extended kinetic method. Rapid Commun. Mass Spectrom. 15, 957-962 (2001). 
20. A.F. Kuntz, A.W. Boynton, G.A. David, K.E. Colyer, J.C. Poutsma, The proton affinity of proline analogs using the kinetic method with full entropy analysis. J. Am. Soc. Mass Spectrom. 13, 72-81 (2002).

21. I.S. Hahn, C. Wesdemiotis, Protonation thermochemistry of $\beta$-alanine: An evaluation of proton affinities and entropies determined by the extended kinetic method. Int. J. Mass Spectrom. 222, 465-479 (2003).

22. a) Z. Wu, C.J. Fenselau, Proton affinities of polyglycines assessed by using the kinetic method. J. Am. Soc. Mass Spectrom. 3, 863-866 (1992).

b) Z. Wu, C.J. Fenselau, Structural Determinants of Gas Phase Basicities of Peptides. Tetrahedron 49, 9197-9206 (1993).

c) X. Cheng, Z. Wu, C.J. Fenselau, Collision energy dependence of proton-bound dimer dissociation: entropy effects, proton affinities, and intramolecular hydrogen-bonding in protonated peptides. J. Am. Chem. Soc. 115, 4844-4848 (1993).

23. M.K. Green, C.B. Lebrilla, Ion-molecule reactions as probes of gas-phase structures of peptides and proteins. Mass Spectrom. Rev. 16, 53-71 (1997).

24. B. Paizs, S. Suhai, Theoretical study of the main fragmentation pathways for protonated glycylglycine. Rapid. Commun. Mass Spectrom. 15, 651-663 (2001). 


\section{Figures Caption}

Figure 1. Plot of the normalized reaction efficiencies for the proton transfer $\mathrm{MH}^{+}+\mathrm{B}_{\mathrm{i}} \rightarrow \mathrm{M}+$ $\mathrm{B}_{\mathrm{i}} \mathrm{H}^{+}$, vs. gas phase basicities of the reference bases $\mathrm{B}_{\mathrm{i}}$. (a) $\mathrm{M}=$ Glycine; (b) M=Alanine; (c) M=Proline; (d) M=Serine; (e) M=Histidine and Lysine.

Figure 2. Plot of the normalized reaction efficiencies for the proton transfer $\mathrm{MH}^{+}+\mathrm{B}_{\mathrm{i}} \rightarrow \mathrm{M}+$ $\mathrm{B}_{\mathrm{i}} \mathrm{H}^{+}$, vs. gas phase basicities of the reference bases $\mathrm{B}_{\mathrm{i}}$. (a) M=GlyGly; (b) M=AlaAla; (c) M=SerSer; (d) M=ProPro; (e) M=AlaGly and GlyAla; (f) M=SerGly and GlySer; (g) M=HisGly and GlyHis; (h) M=GlyLys; (i) M=LysGly; (j) M=GlyPro; (k) M=ProGly.

Figure 3. Plot of the normalized reaction efficiencies for the proton transfer $\mathrm{MH}^{+}+\mathrm{B}_{\mathrm{i}} \rightarrow \mathrm{M}+$ $\mathrm{B}_{\mathrm{i}} \mathrm{H}^{+}$, vs. gas phase basicities of the reference bases $\mathrm{B}_{\mathrm{i}}$. (a) $\mathrm{M}=$ GlyGlyGly; (b) $\mathrm{M}=\mathrm{AlaGlyGly}$, GlyAlaGly and GlyGlyAla; (c) M=GlyGlyPro; (d) M=GlyProGly; (e) M=ProGlyGly; (f) M=HisGlyGly, GlyHisGly and GlyGlyHis; (g) M=LysGlyGly, GlyLysGly and GlyGlyLys; (h) $\mathrm{M}=(\text { Gly })_{4}$, (Gly) 5 and (Gly) 6 .

Figure 4. Evolution of the gas phase basicity of polyglycines with the number of residues. 


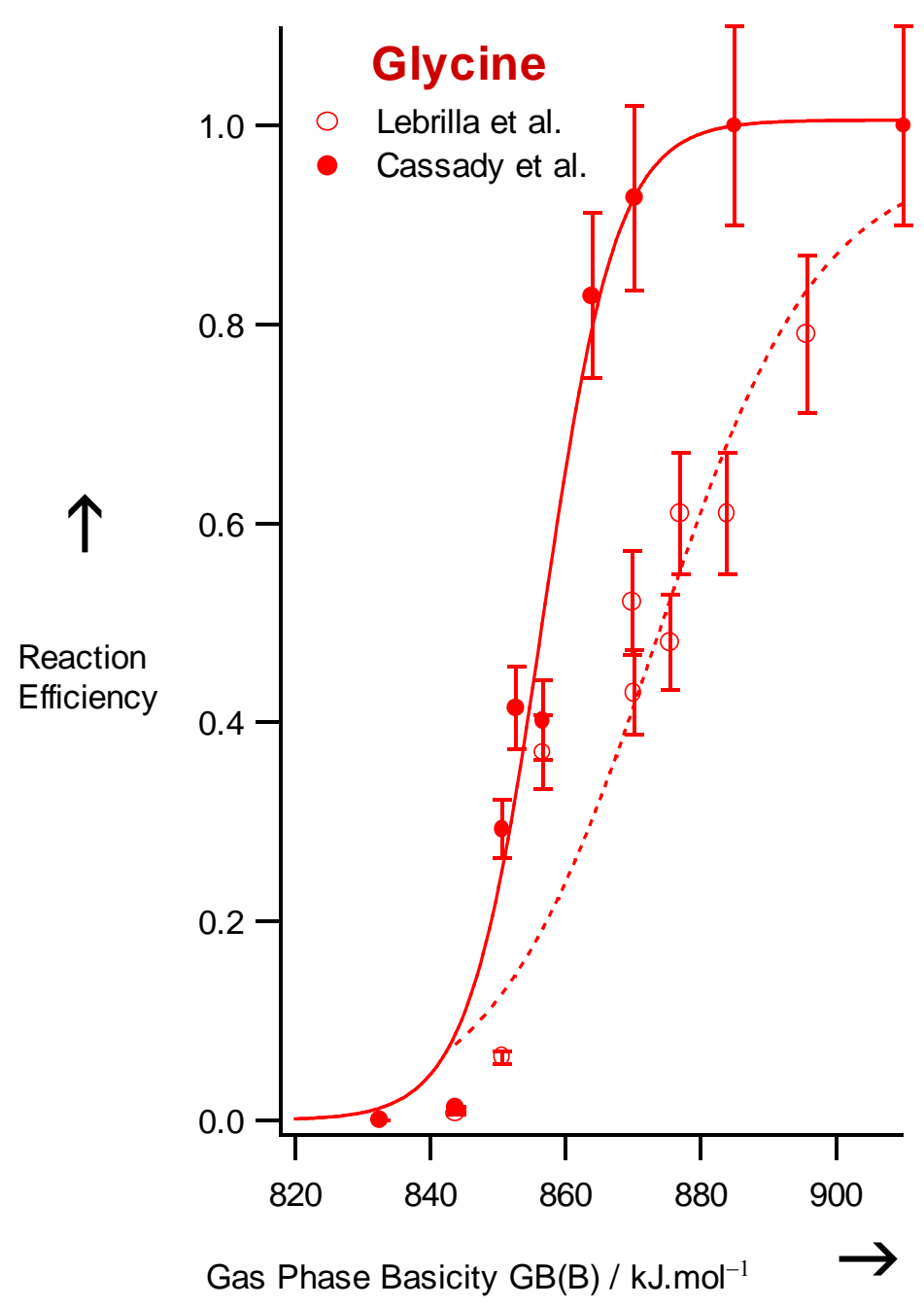

Fig 1a 


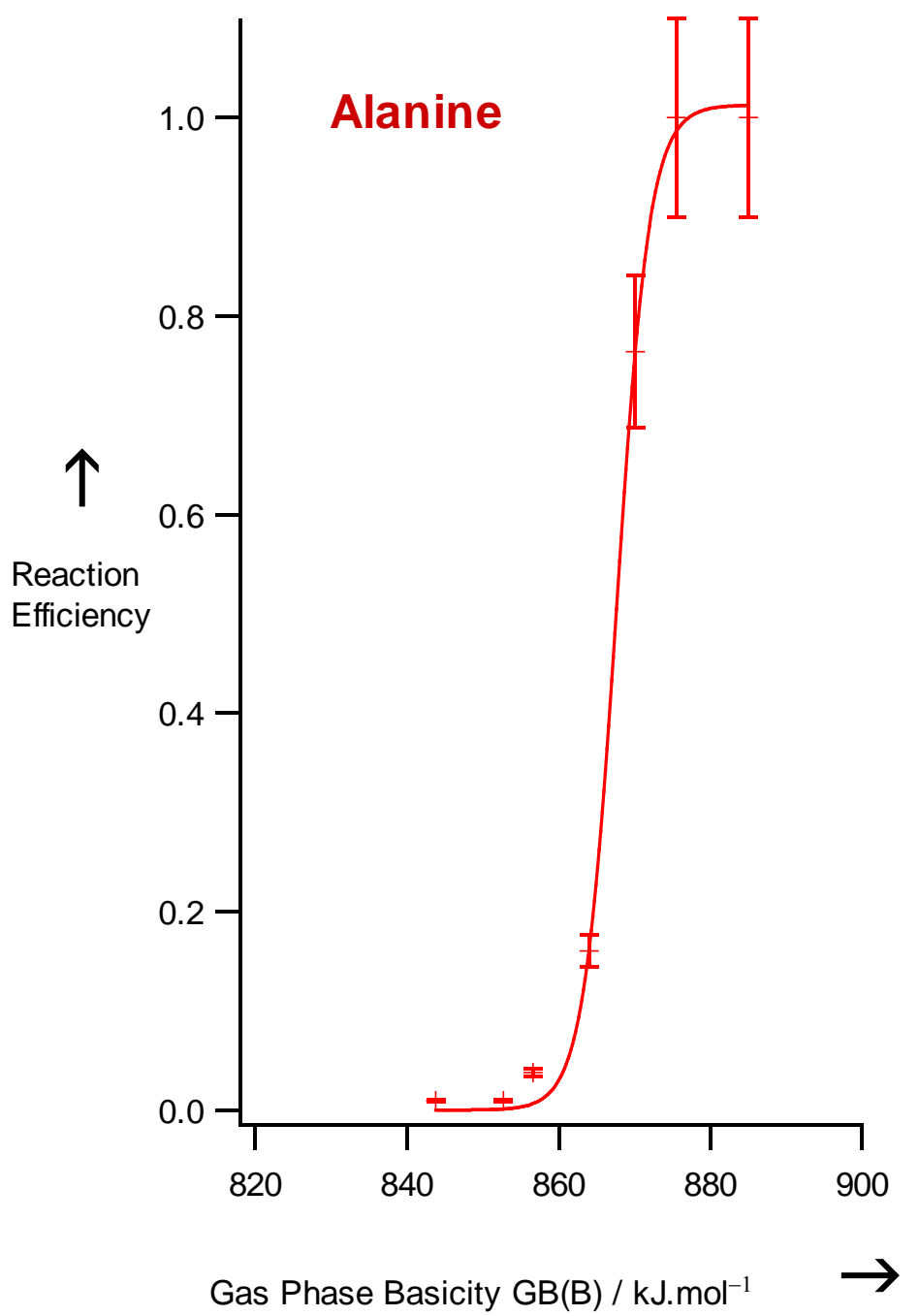

Figure 1b 


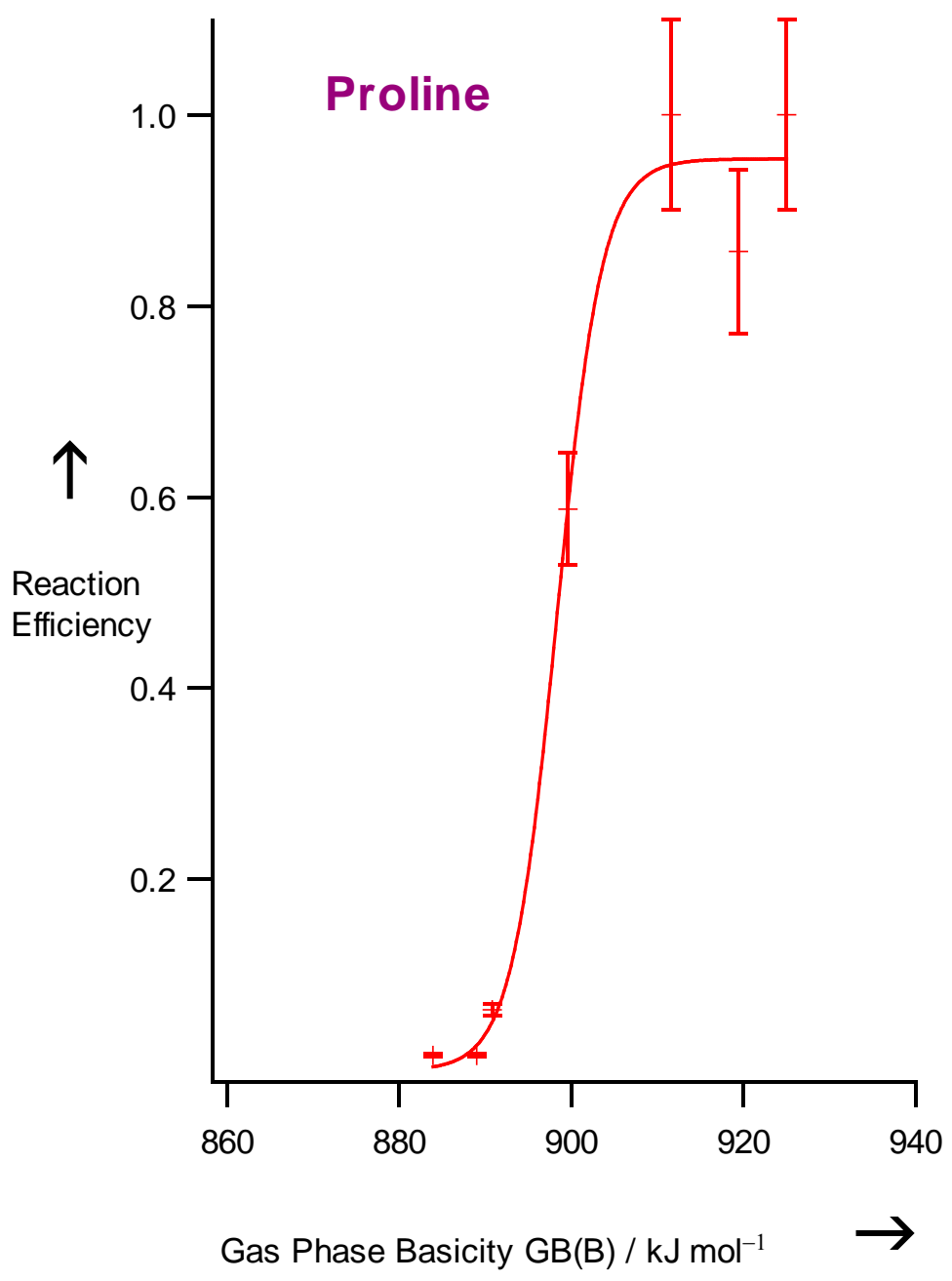

Figure 1c 


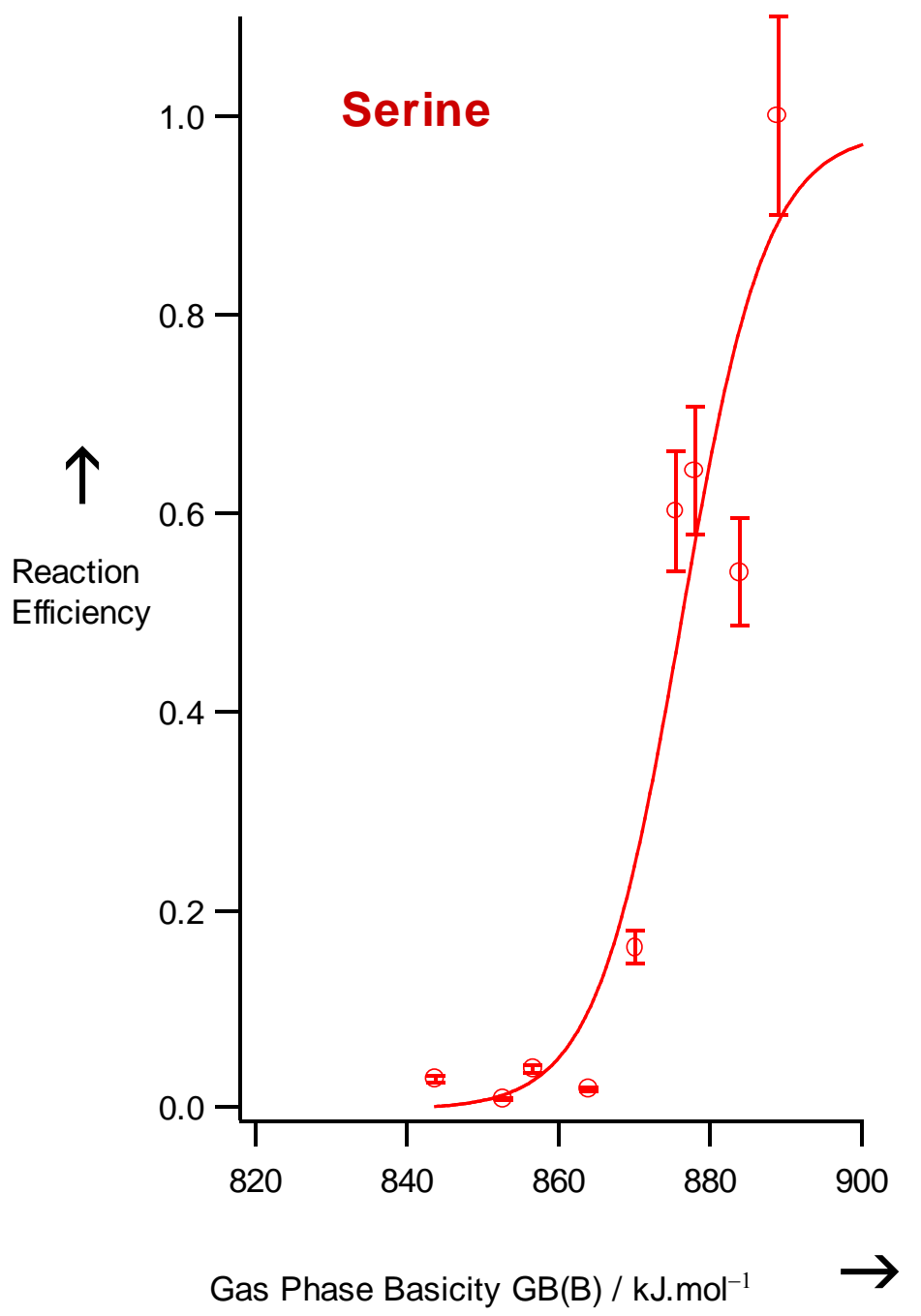

Figure 1d 


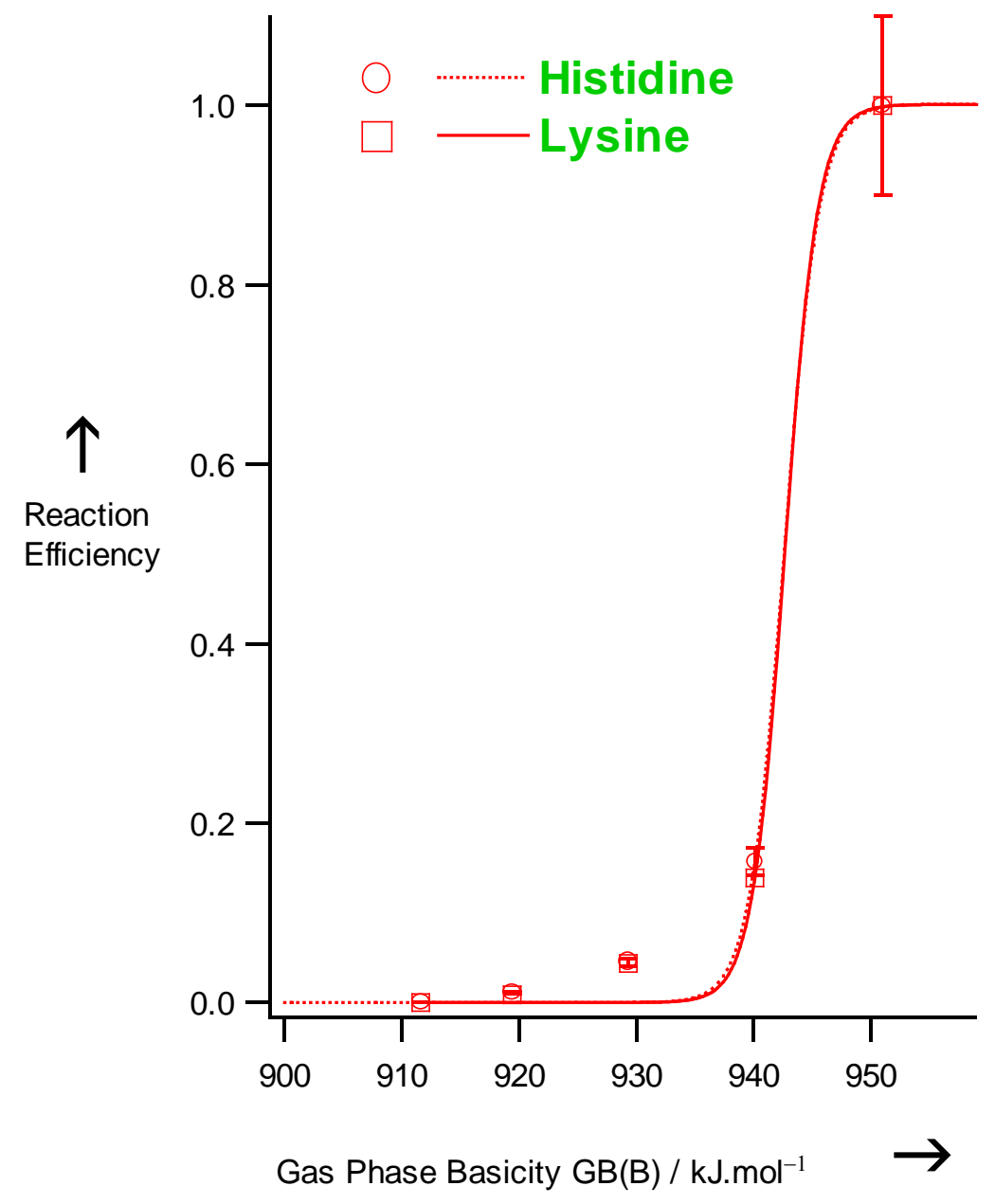

Figure 1e 


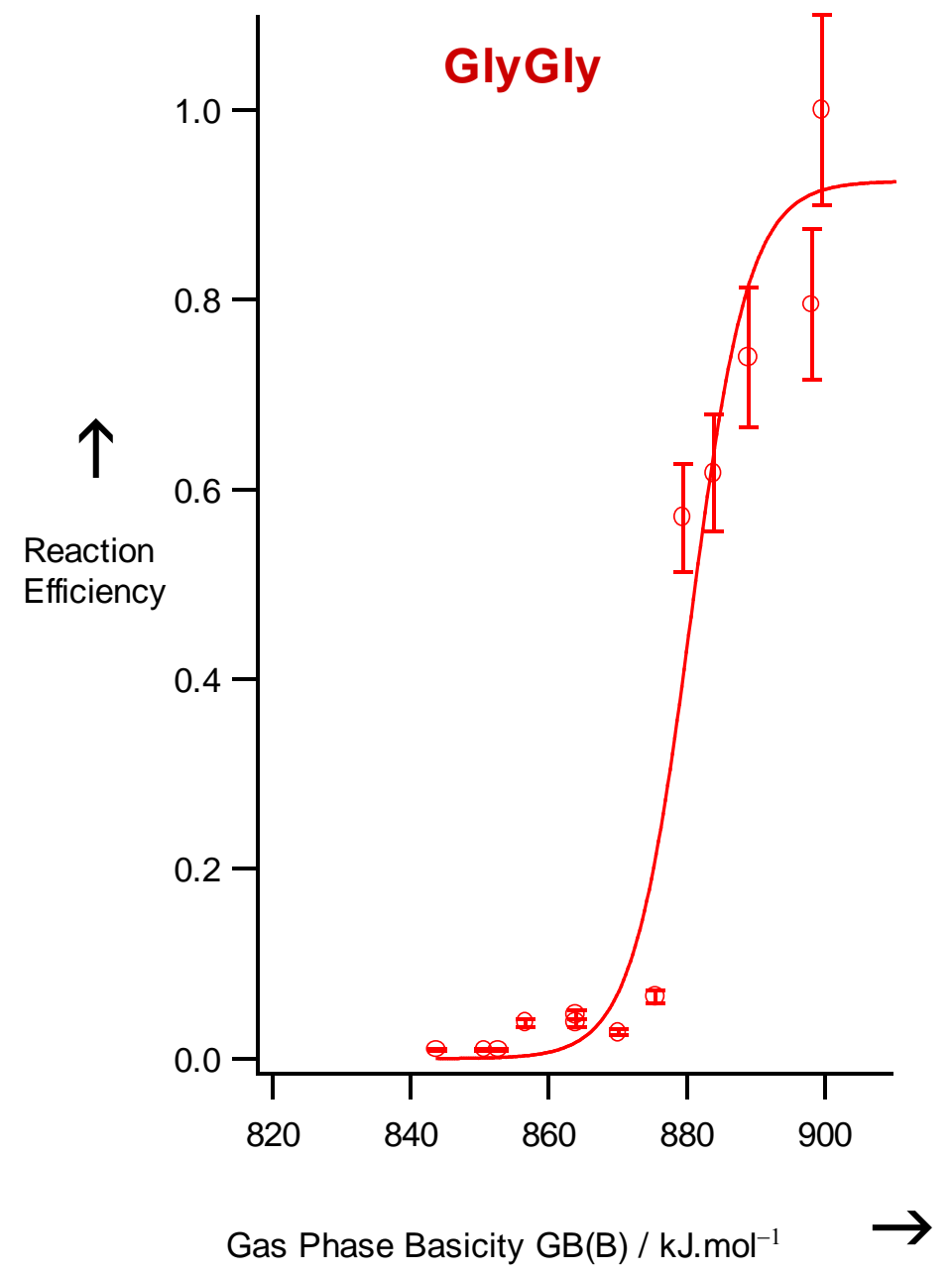

Figure 2a 


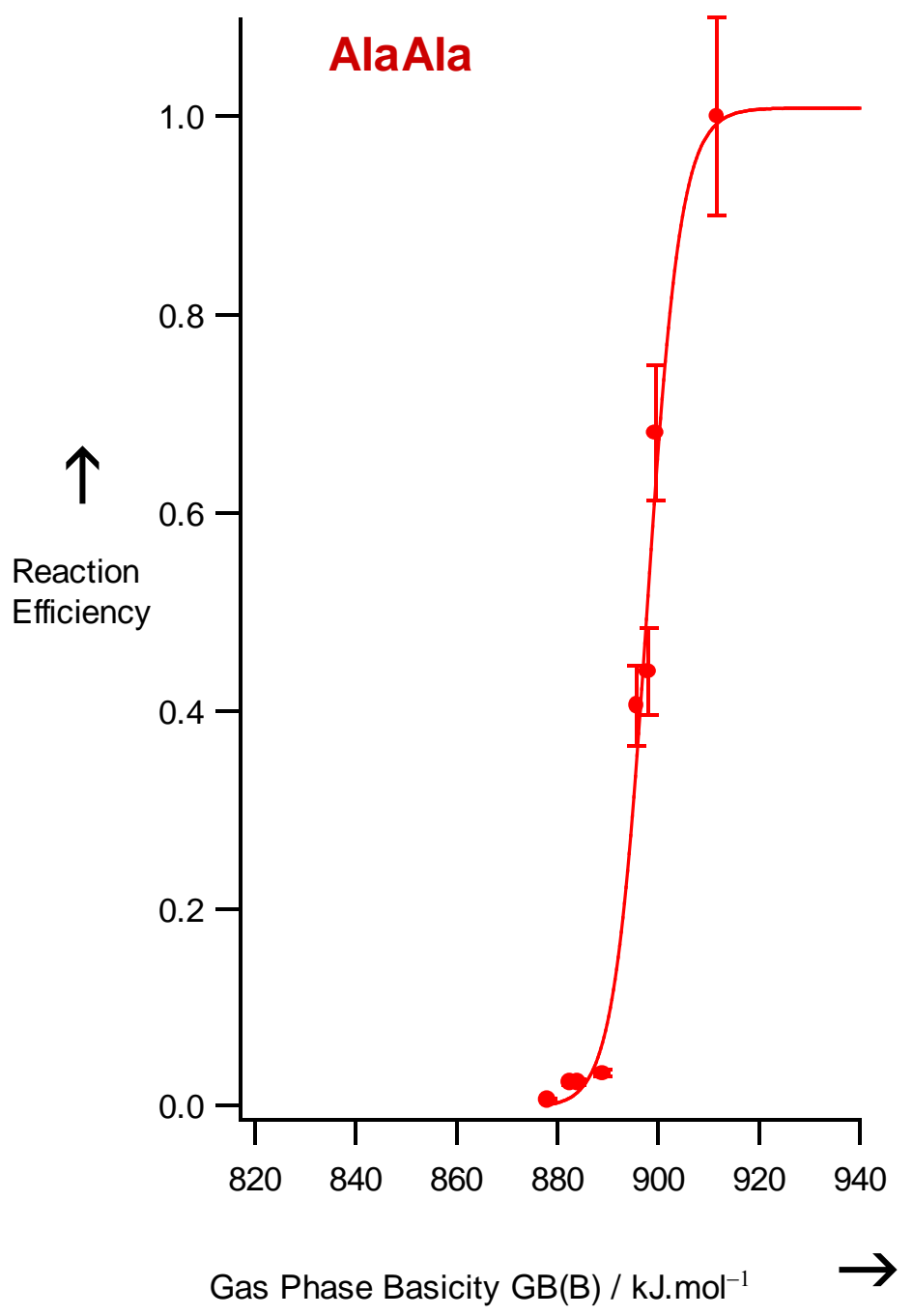

Figure 2b 


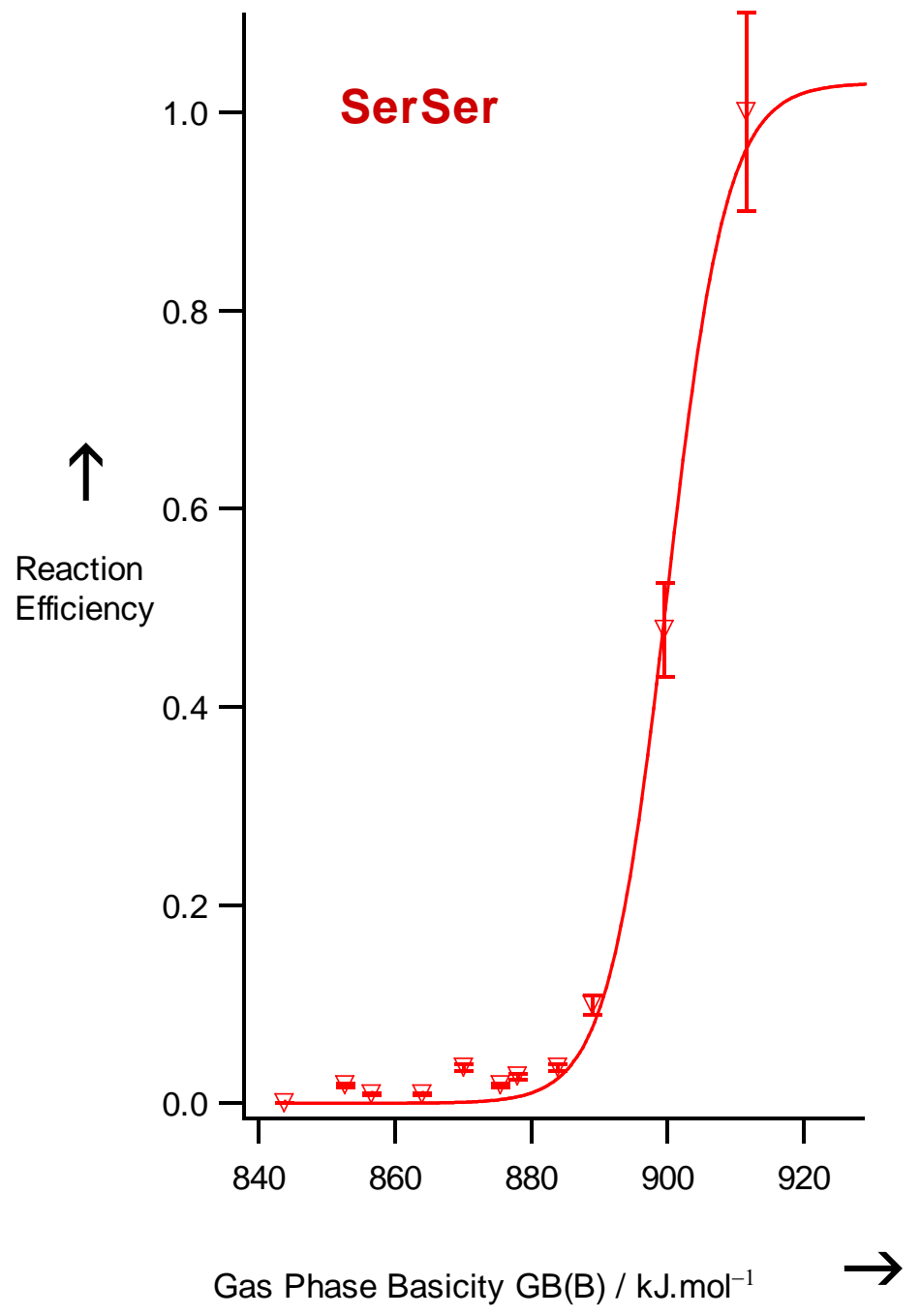

Figure 2c 


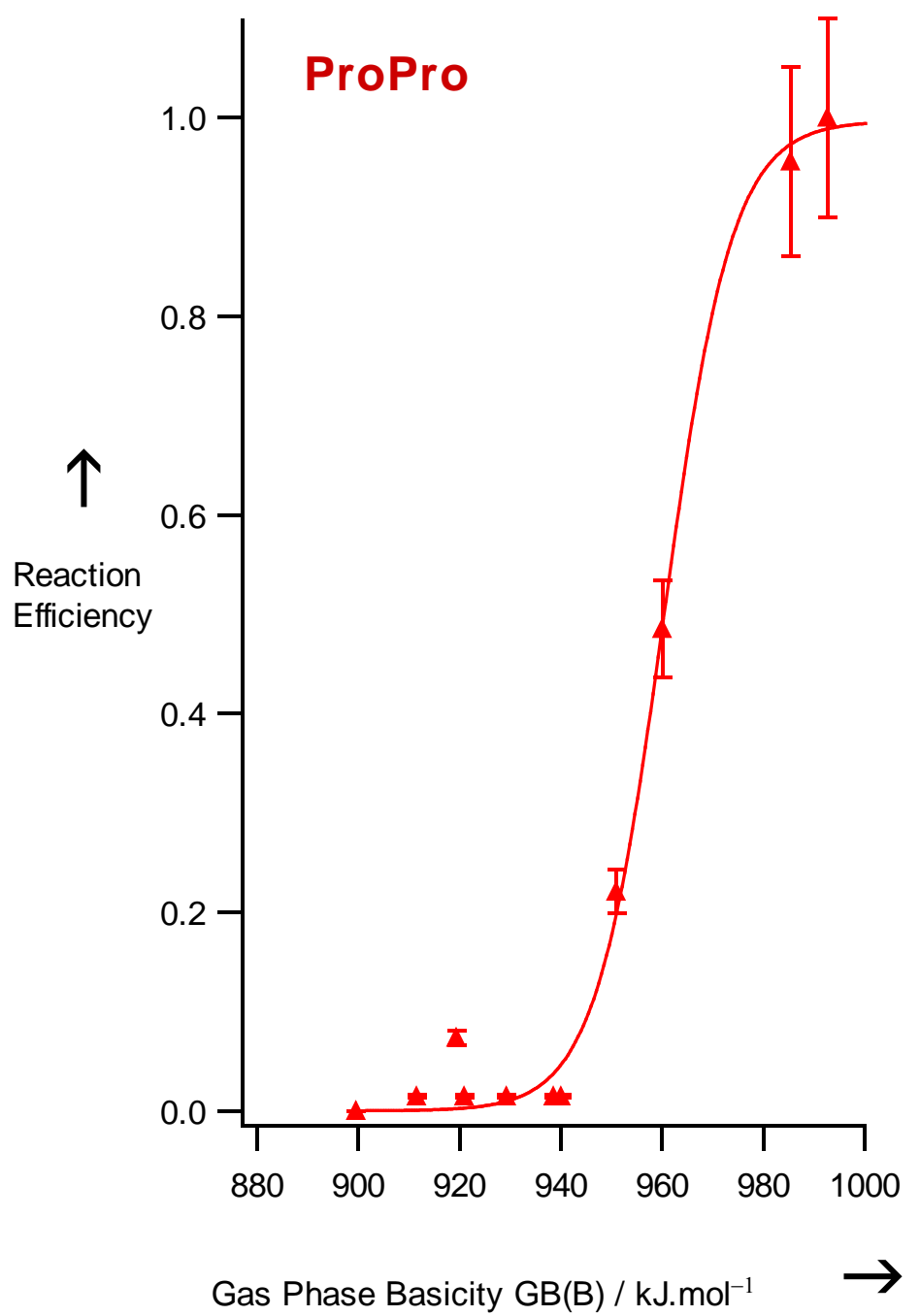

Figure 2d 


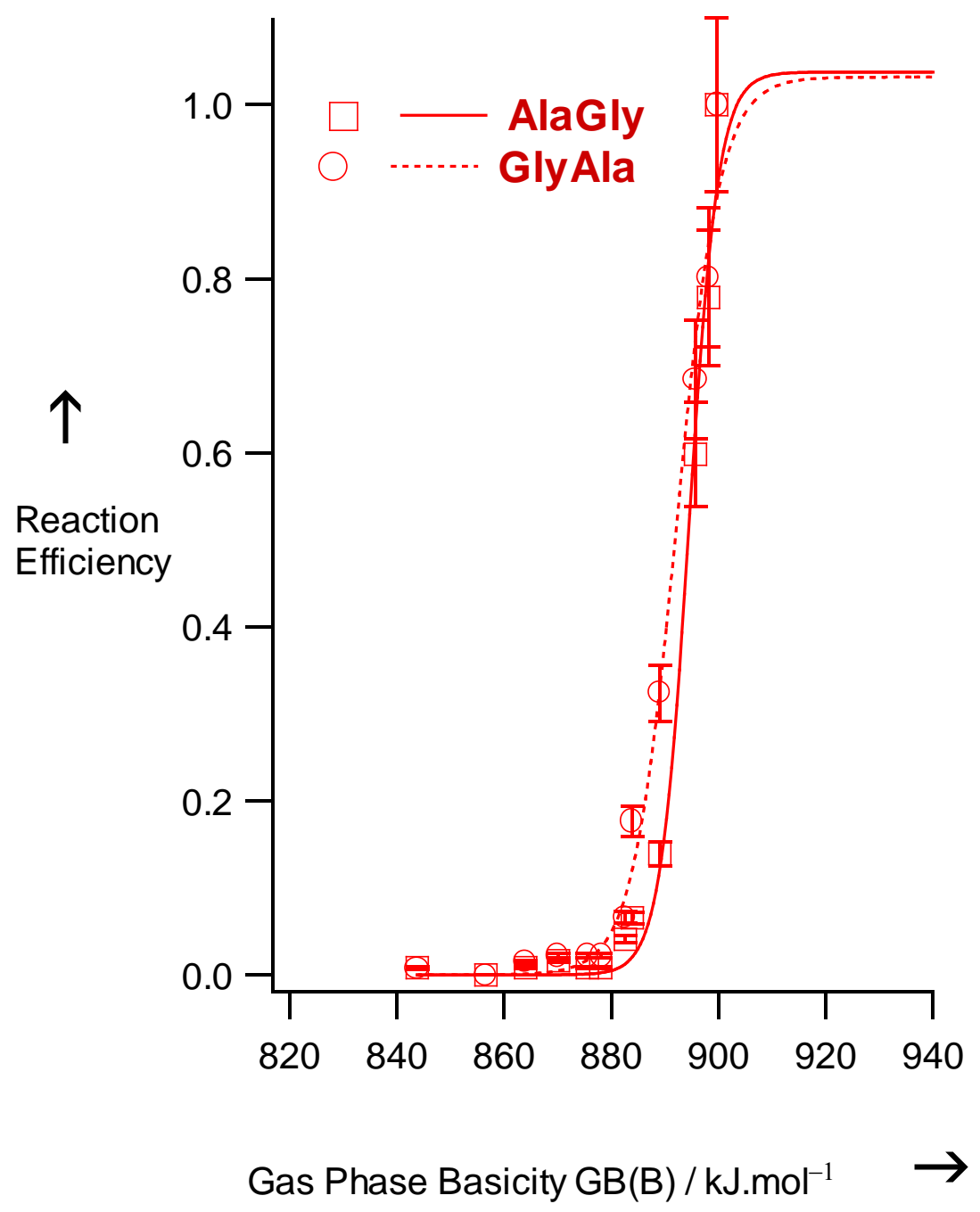

Figure 2e 


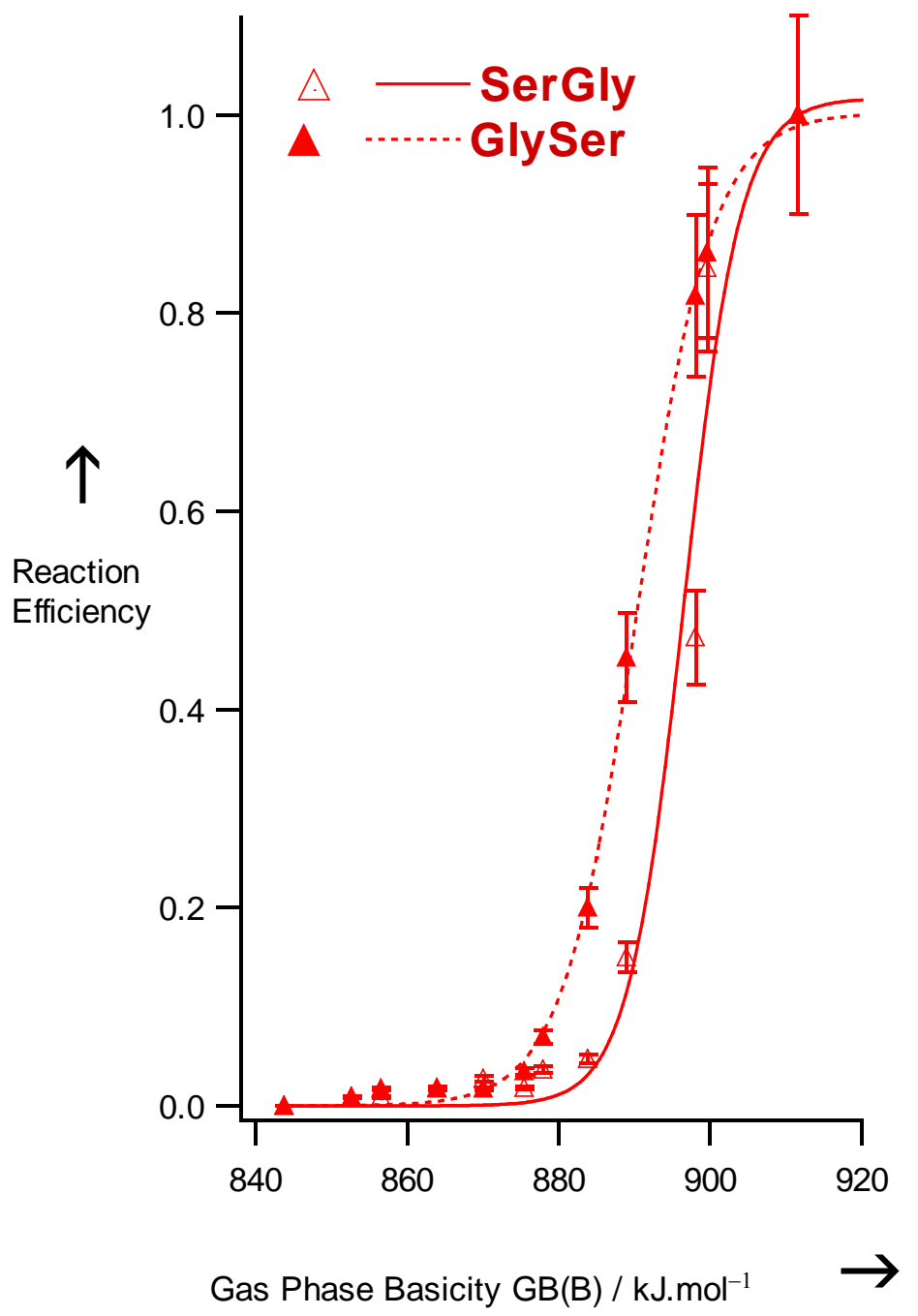

Figure 2f 


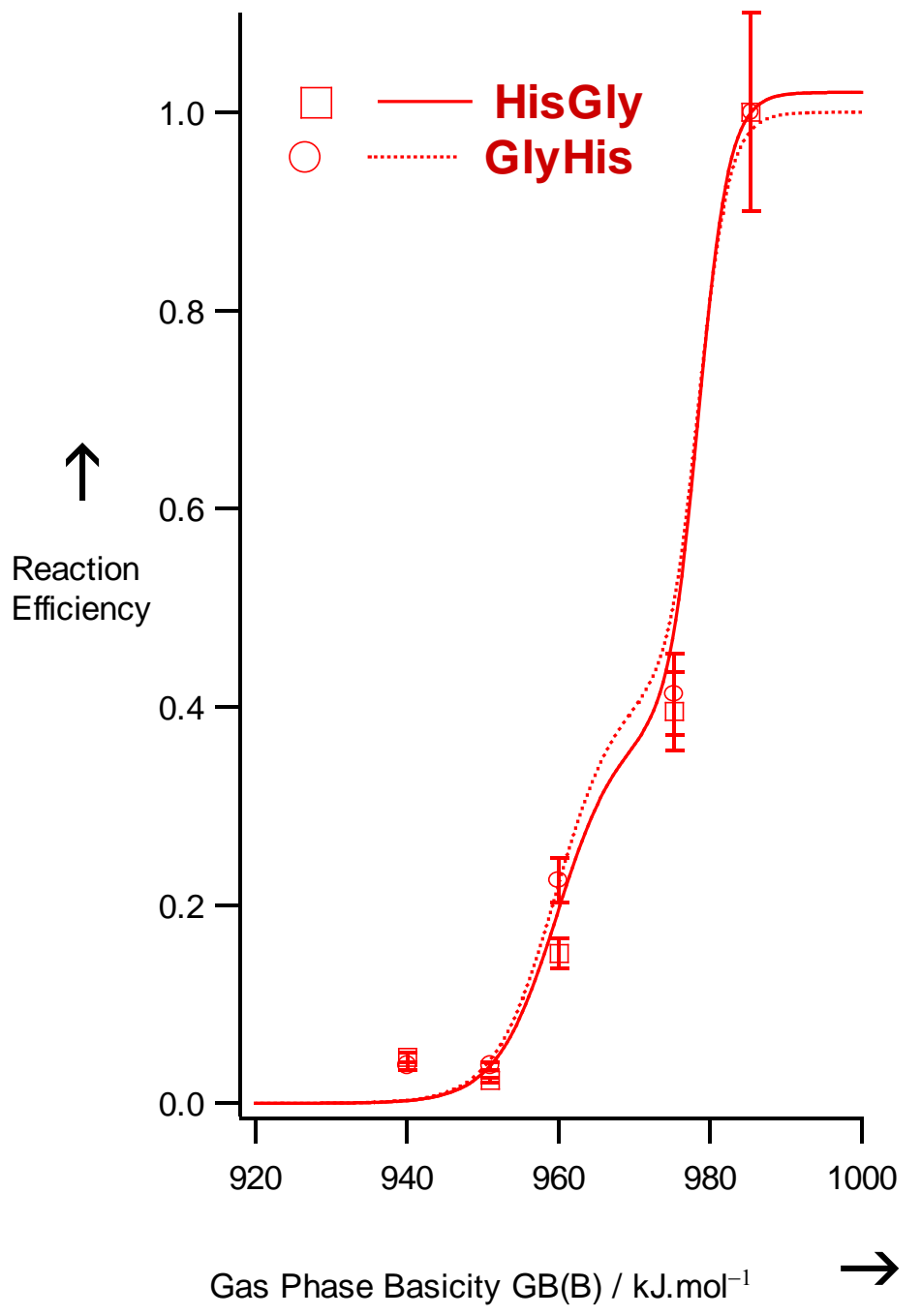

Figure 2g 


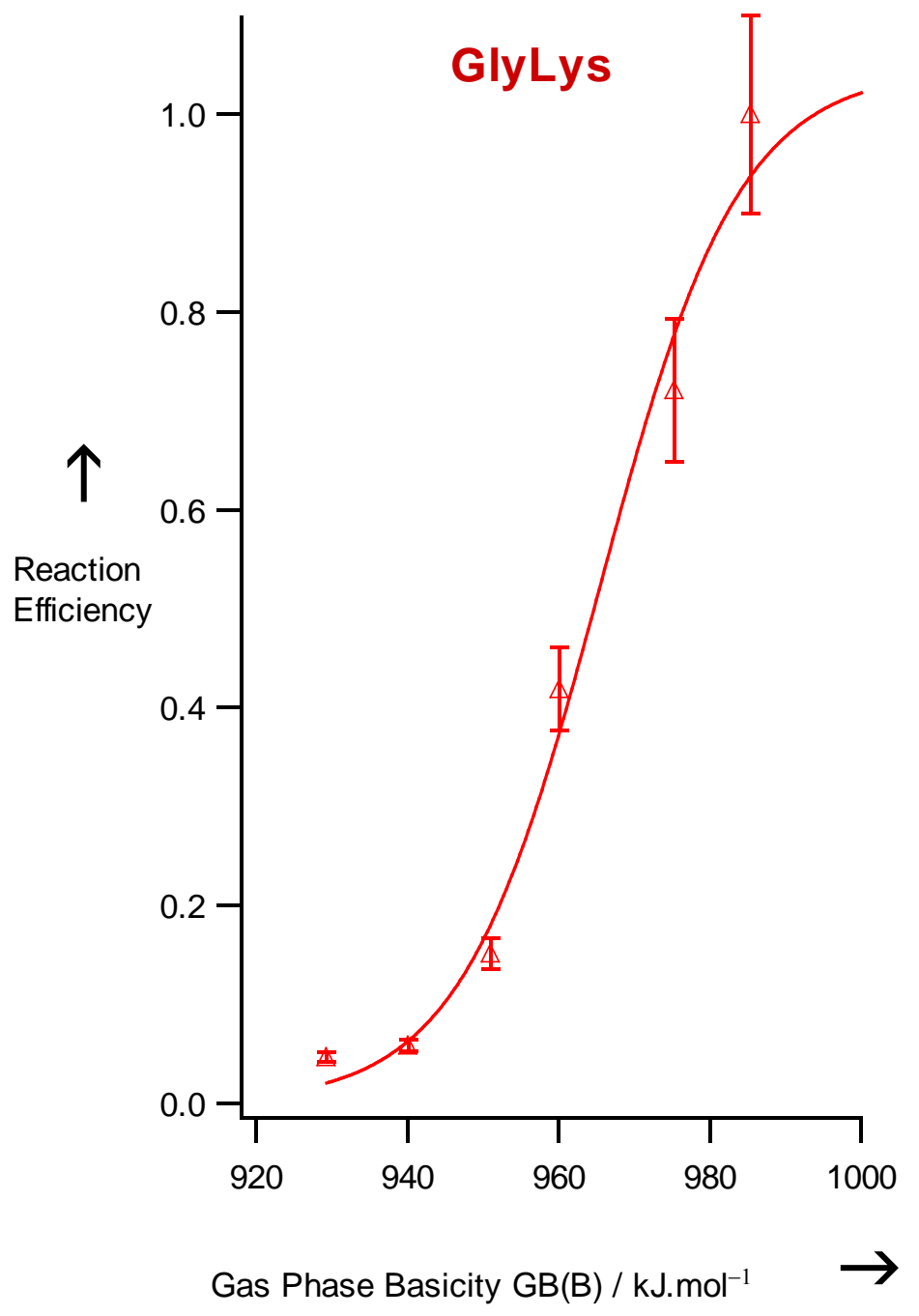

Figure 2h 


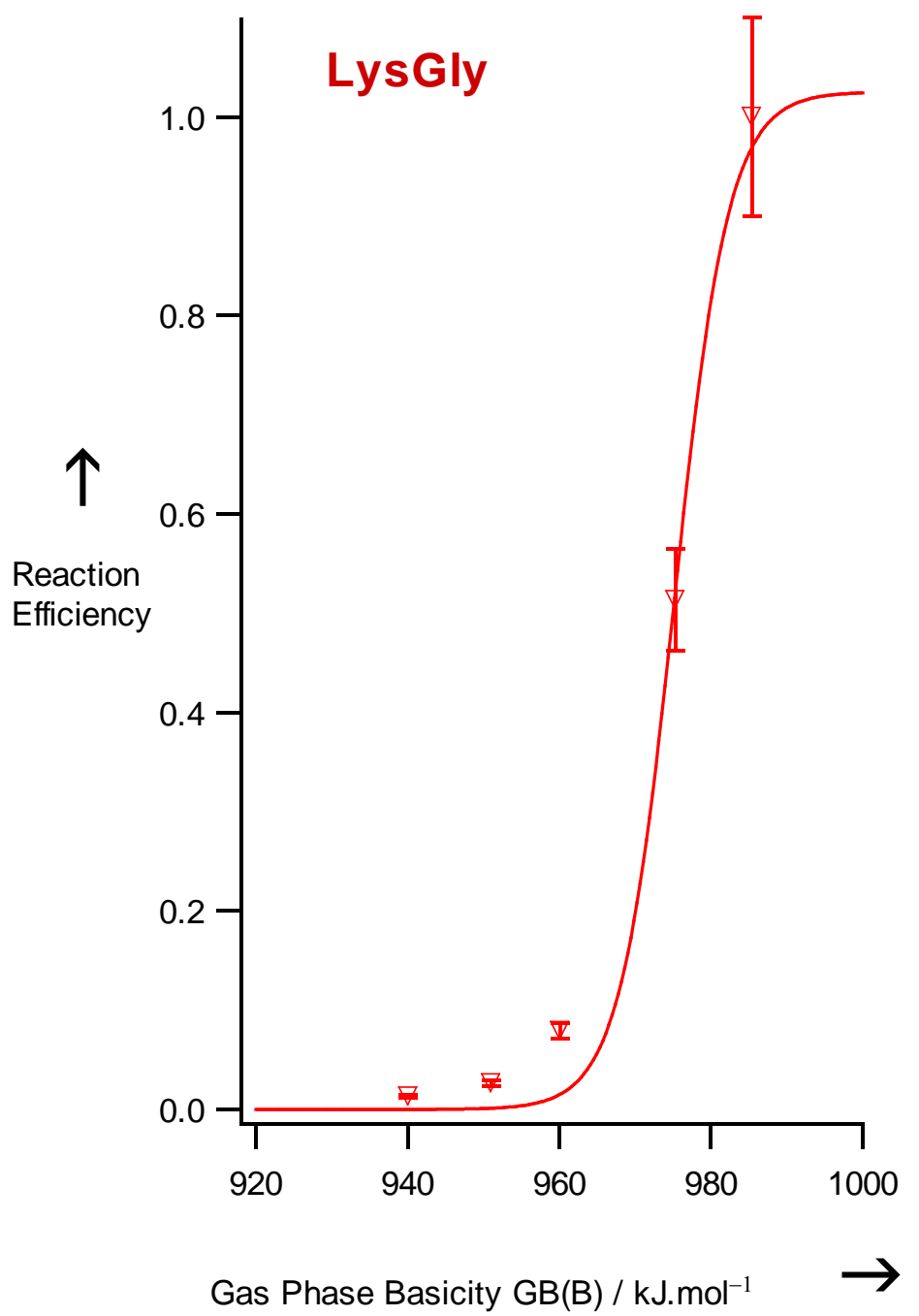

Figure 2i 


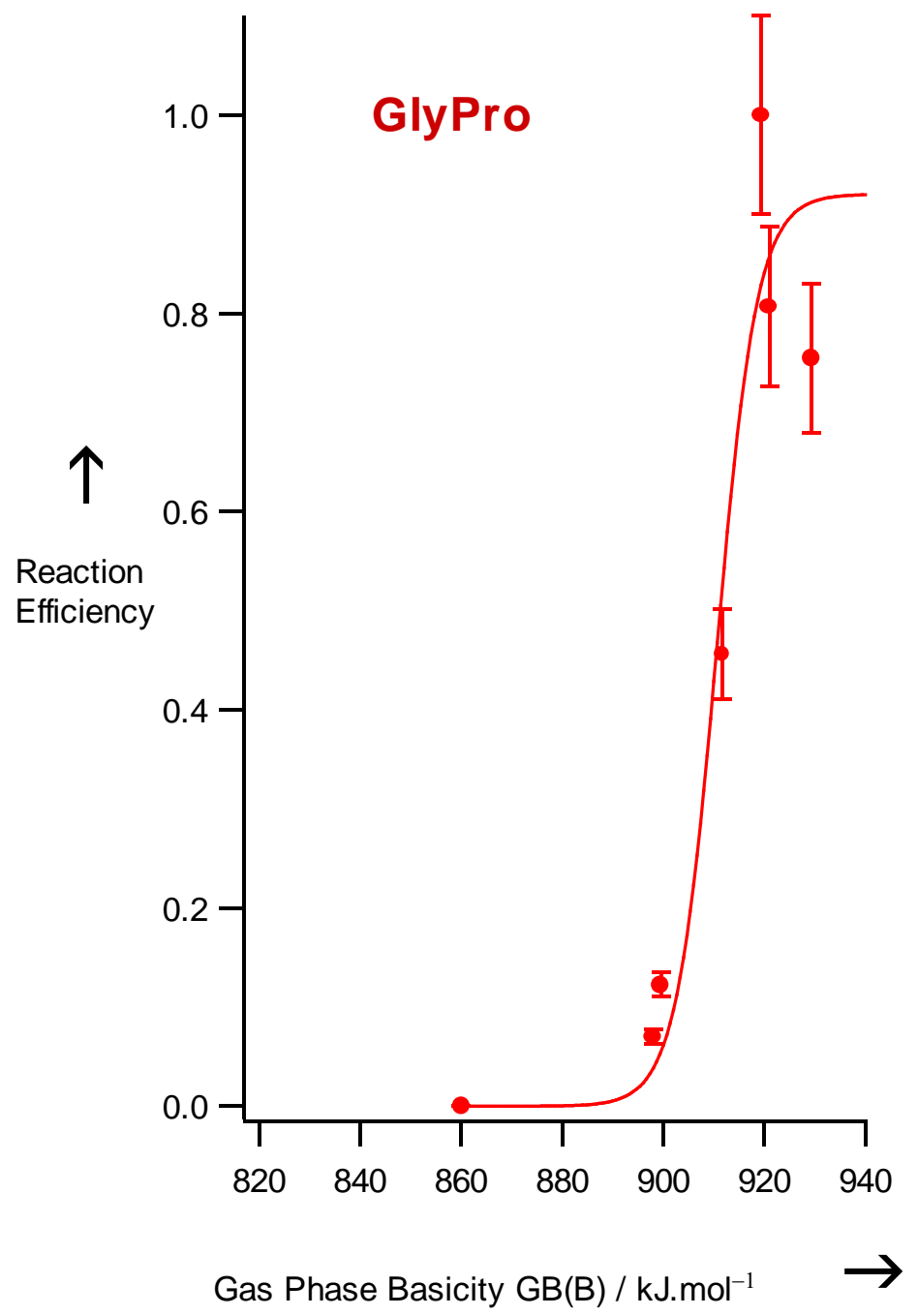

Figure 2j 


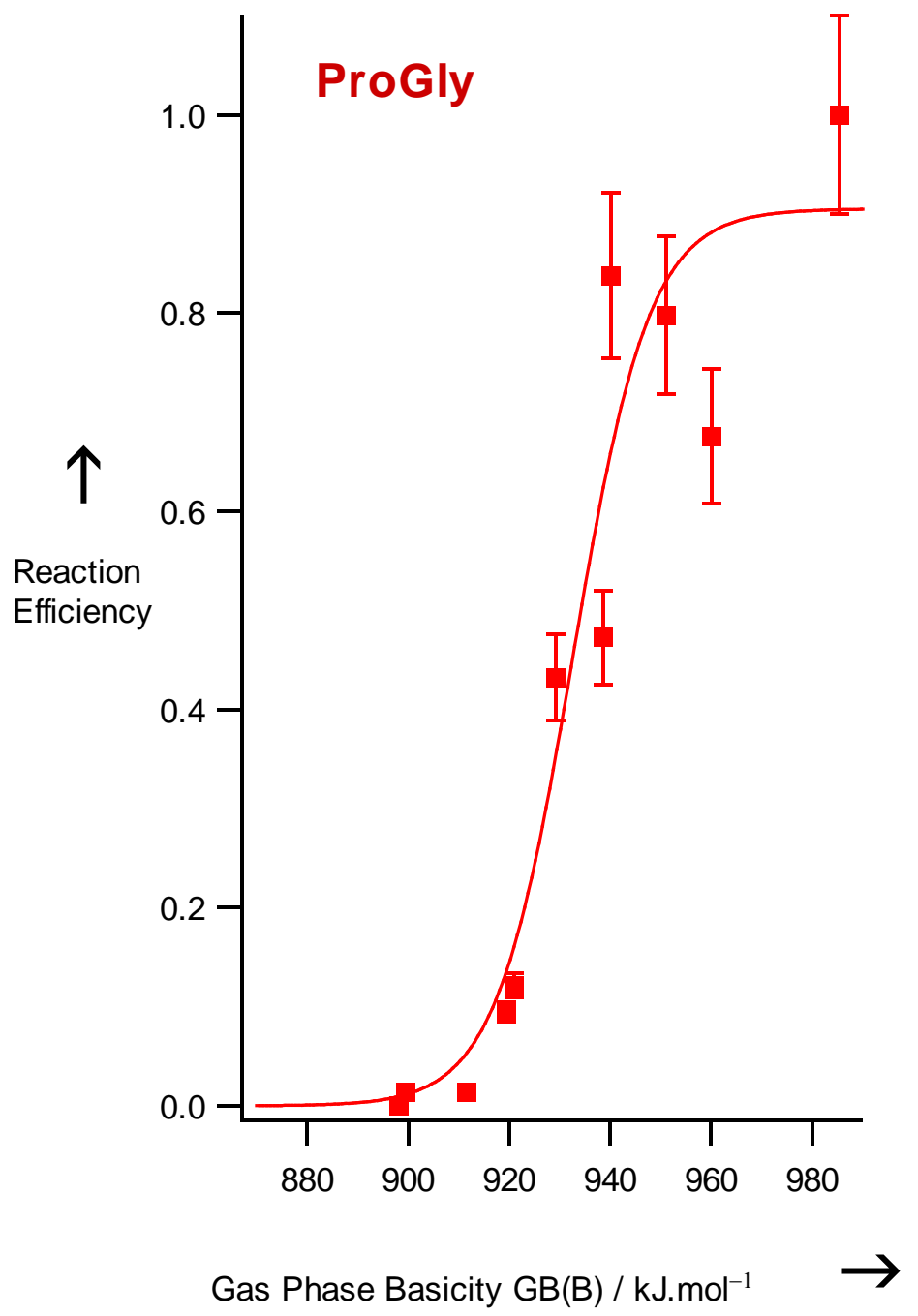

Figure 2k 


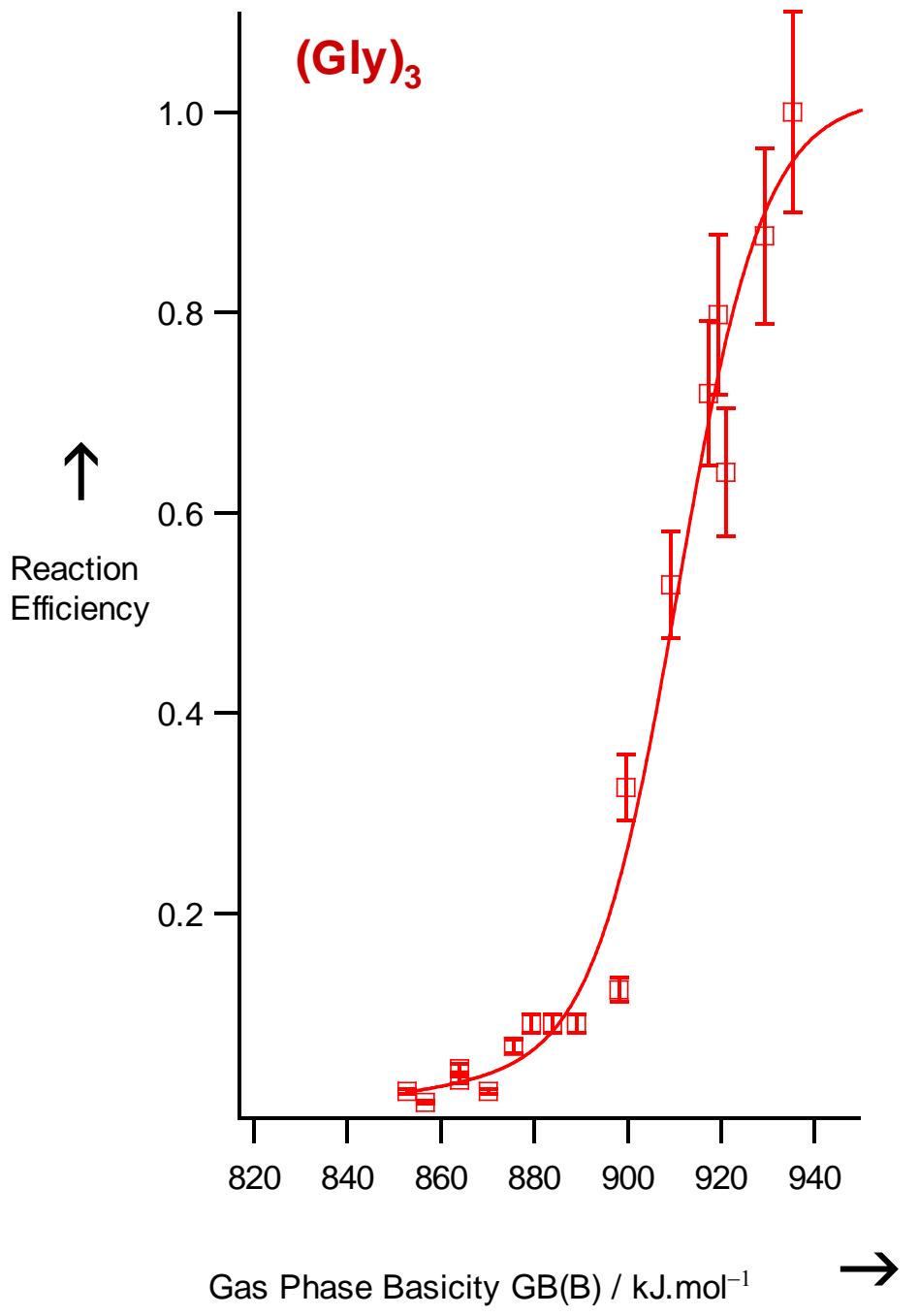

Figure 3a 


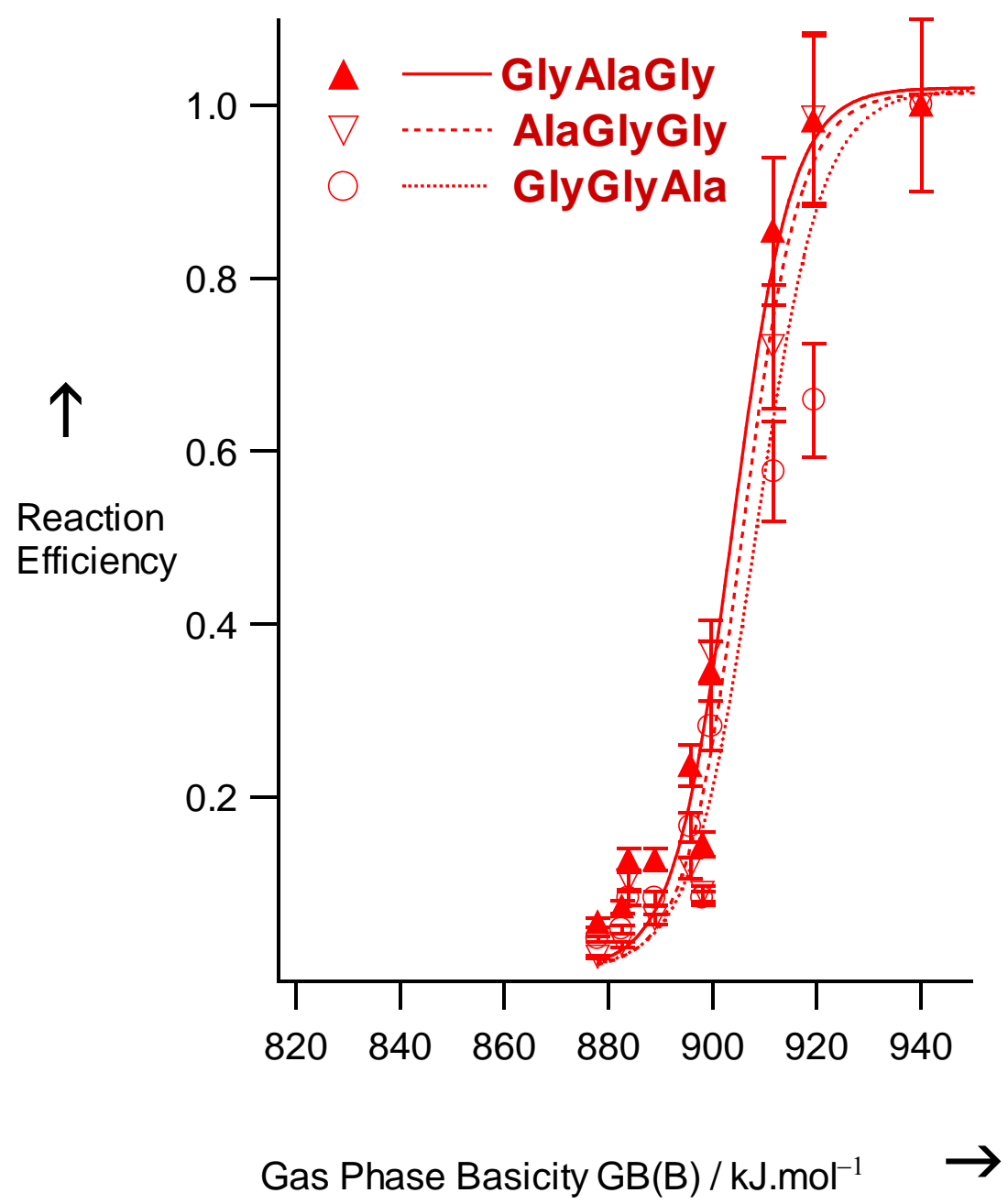

Figure 3b 


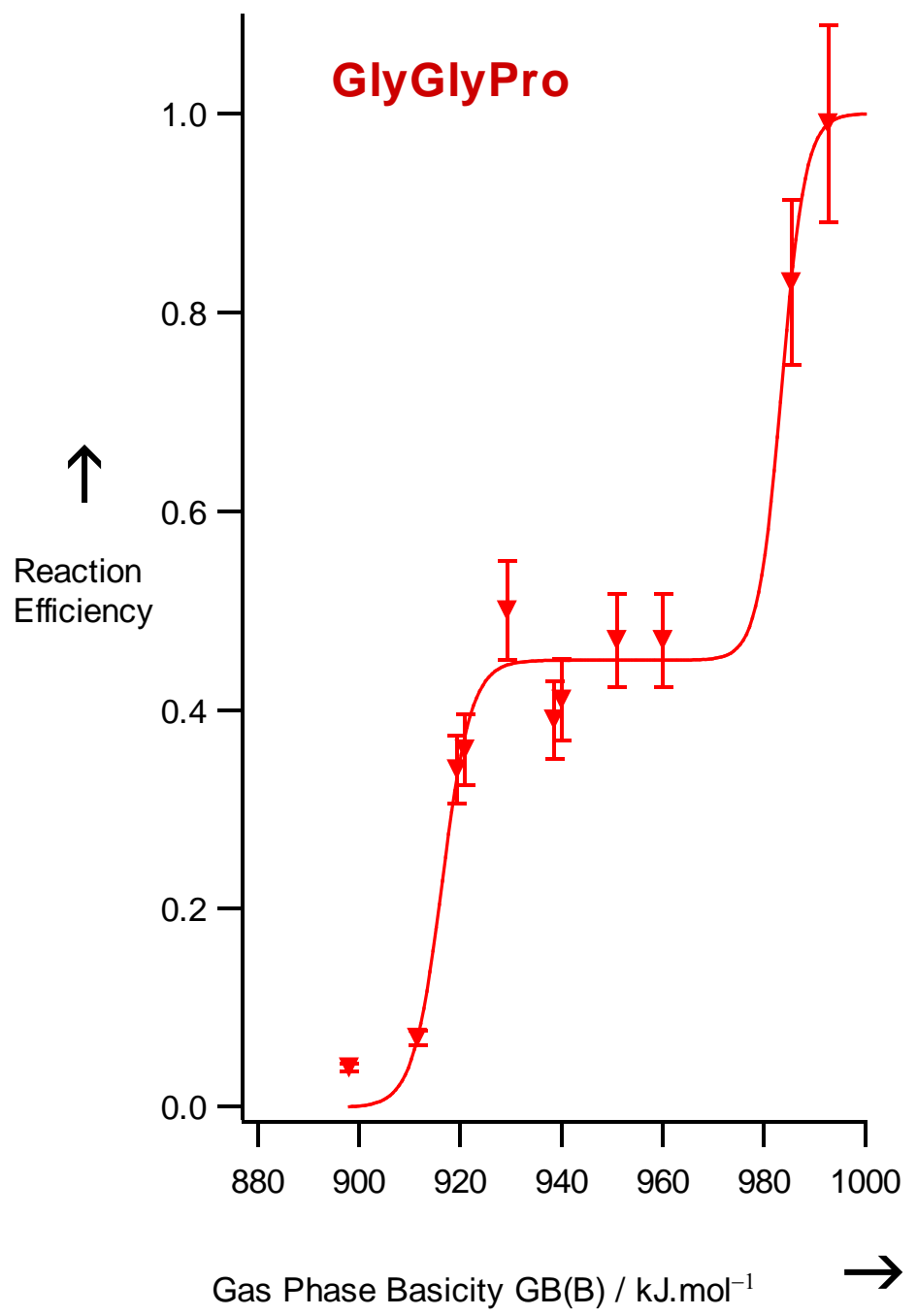

Figure 3c 


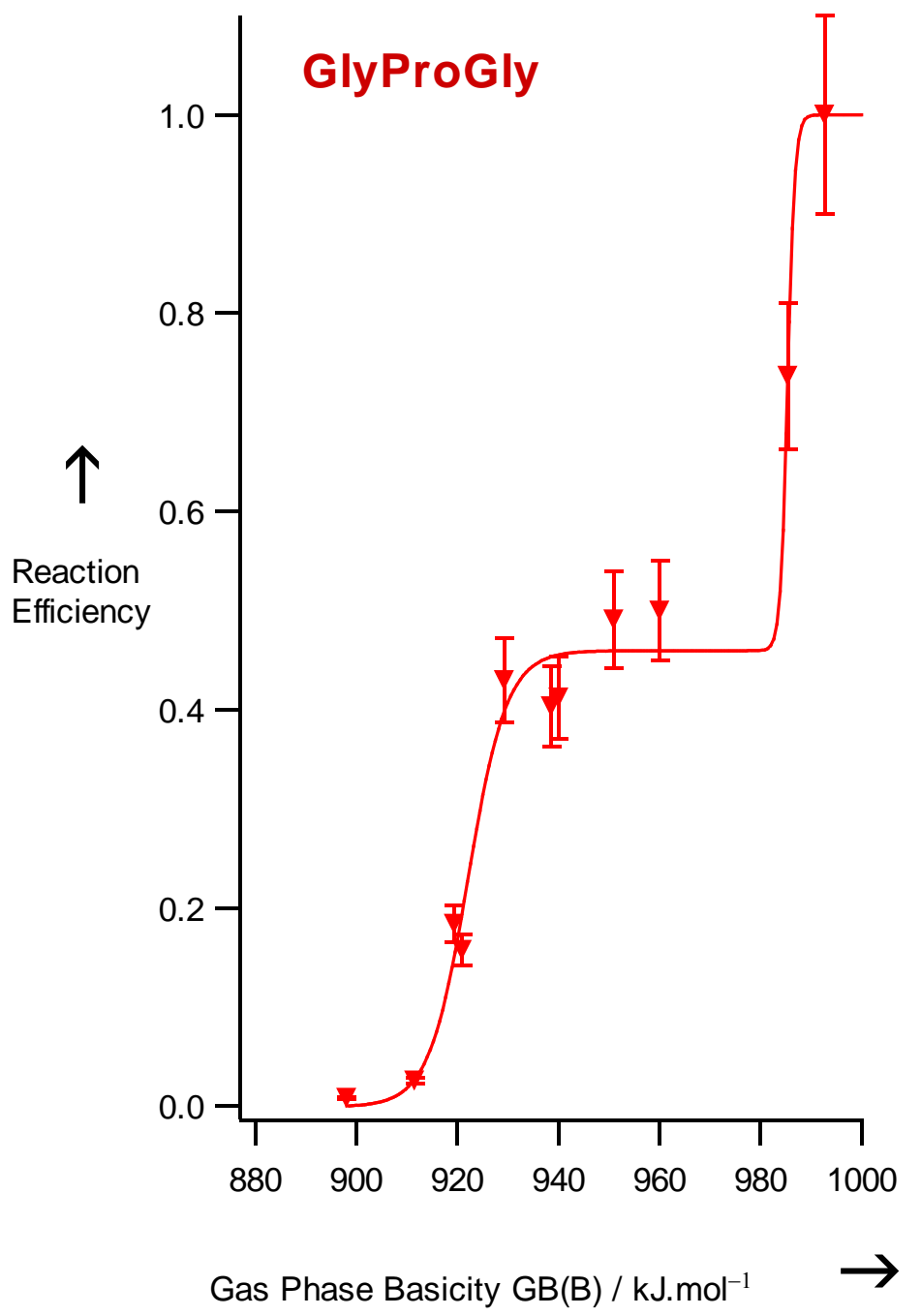

Figure 3d 


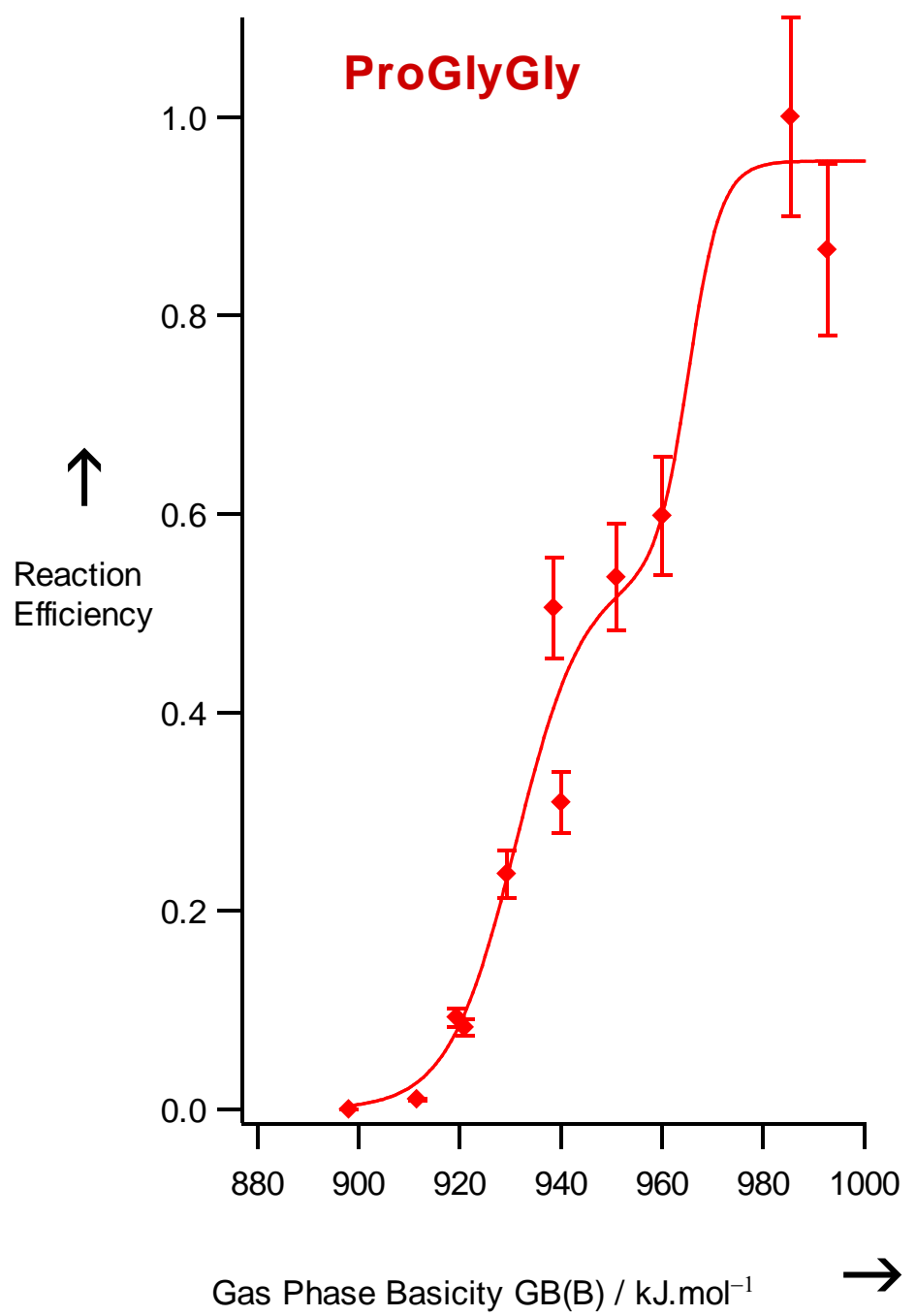

Figure 3e 


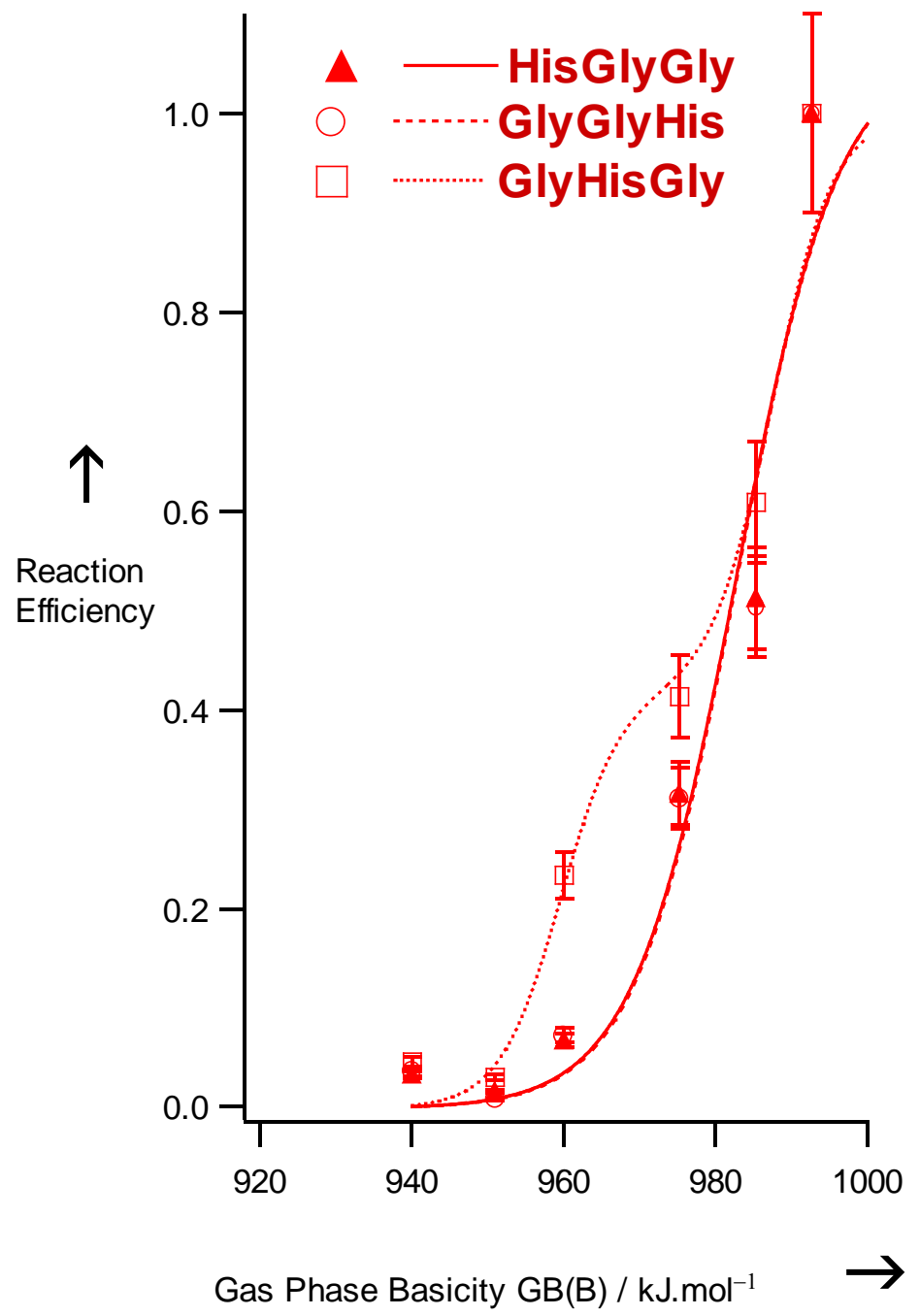

Figure 3f 


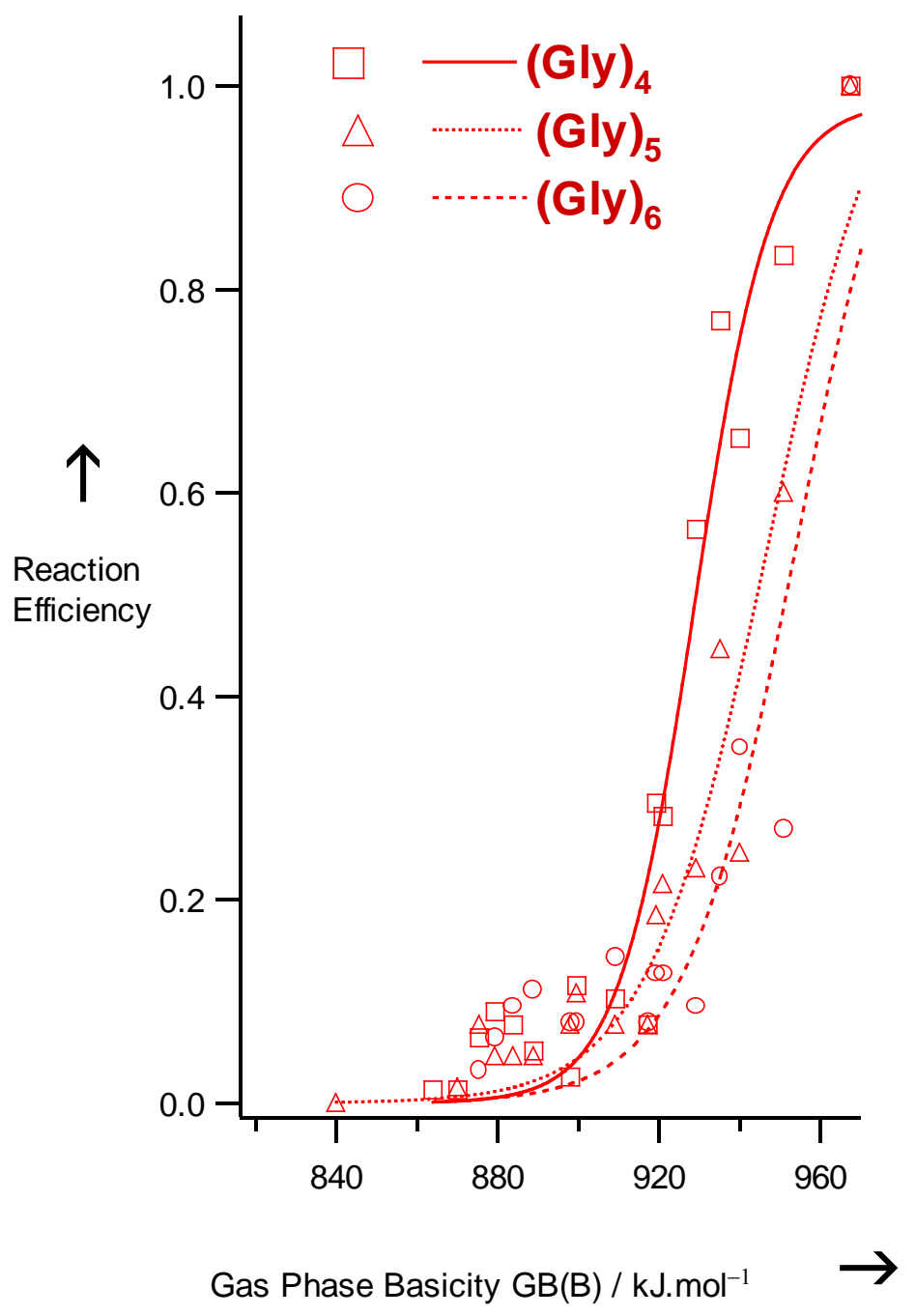

Figure 3g 


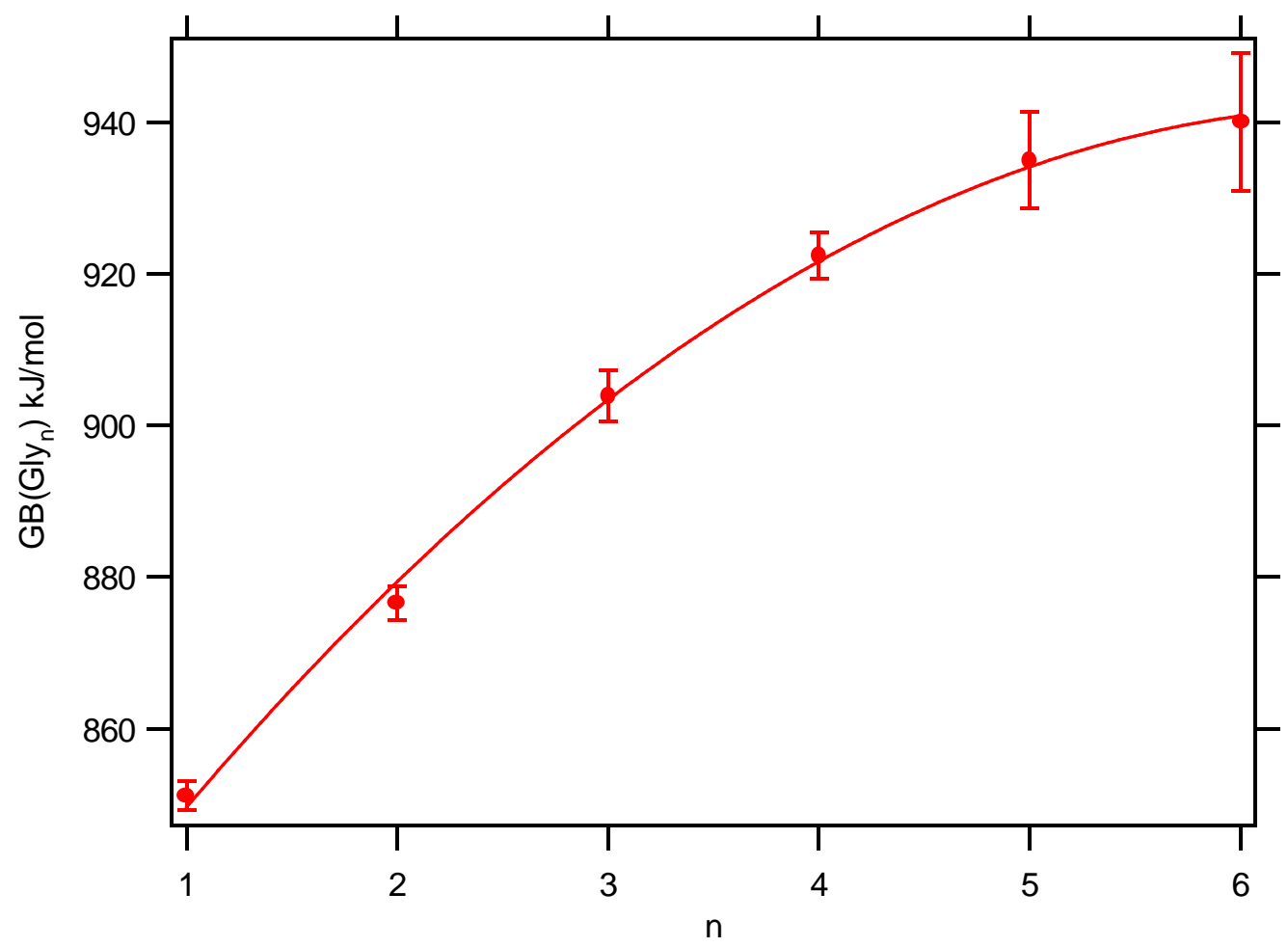

Figure 4 
Table 1. Thermokinetic coefficients a, b (mol/kJ) and c (kJ/mol) (see eq. 3)

\begin{tabular}{|c|c|c|c|c|}
\hline $\mathbf{M}$ & $\mathbf{a}$ & $\mathbf{b}$ & c & ref. \\
\hline Gly & 1.00 & 0.18 & 856.6 & 6 \\
\hline Ala & 1.01 & 0.46 & 867.6 & 8 \\
\hline Pro & 0.95 & 0.38 & 898.3 & 9 \\
\hline Ser & 0.98 & 0.18 & 876.2 & 7 \\
\hline Lys & 1.00 & 0.72 & 942.6 & 10 \\
\hline His & 1.00 & 0.67 & 942.6 & 10 \\
\hline GlyGly & 0.92 & 0.24 & 880.5 & 6 \\
\hline AlaAla & 1.00 & 0.30 & 897.8 & 8 \\
\hline SerSer & 1.03 & 0.23 & 899.9 & 7 \\
\hline ProPro & 1.00 & 0.15 & 960.3 & 9 \\
\hline GlyAla & 1.03 & 0.25 & 892.1 & 8 \\
\hline AlaGly & 1.04 & 0.37 & 894.5 & 8 \\
\hline GlySer & 1.00 & 0.20 & 890.4 & 7 \\
\hline SerGly & 1.02 & 0.27 & 896.6 & 7 \\
\hline GlyHis & $0.42(0.58)^{*}$ & $0.25(0.5)^{*}$ & $959.6(978.5)^{*}$ & 10 \\
\hline HisGly & $0.38(0.64)^{*}$ & $0.25(0.5)^{*}$ & 959.8(978.5)* & 10 \\
\hline GlyLys & 1.05 & 0.11 & 965.5 & 10 \\
\hline LysGly & 1.02 & 0.28 & 975.1 & 10 \\
\hline GlyPro & 0.92 & 0.24 & 910.5 & 9 \\
\hline ProGly & 0.91 & 0.13 & 932.6 & 9 \\
\hline GlyGlyGly & 1.00 & 0.12 & 911.9 & 6 \\
\hline GlyGlyAla & 1.02 & 0.16 & 908.4 & 8 \\
\hline GlyAlaGly & 1.02 & 0.18 & 903.8 & 8 \\
\hline AlaGlyGly & 1.01 & 0.18 & 905.7 & 8 \\
\hline GlyGlyPro & $0.45(0.55)^{*}$ & $0.35(0.43)^{*}$ & $916.4(983.5)^{*}$ & 9 \\
\hline GlyProGly & $0.46(0.54)^{*}$ & $0.26(1.39)^{*}$ & 922.1(985.4)* & 9 \\
\hline ProGlyGly & $0.54(0.42)^{*}$ & $0.15(0.33) *$ & 931.1(964.9)* & 9 \\
\hline GlyGlyHis & 1.07 & 0.15 & 982.9 & 10 \\
\hline GlyHisGly & $0.42(0.58)^{*}$ & $0.28(0.25)^{*}$ & 959.3(987.5)* & 10 \\
\hline HisGlyGly & 1.07 & 0.15 & 982.8 & 10 \\
\hline GlyGlyLys & 1.04 & 0.19 & 994.4 & 10 \\
\hline GlyLysGly & 1.04 & 0.12 & 977.1 & 10 \\
\hline LysGlyGly & 1.04 & 0.19 & 992.9 & 10 \\
\hline$(\text { Gly })_{4}$ & 0.95 & 0.14 & 929.8 & 6 \\
\hline$\left(\right.$ Gly) ${ }_{5}$ & 1.07 & 0.07 & 946.9 & 6 \\
\hline (Gly)6 & 1.11 & 0.07 & 954.3 & 6 \\
\hline
\end{tabular}

* Two components reaction efficiency curves (see text and Figures). 
Table2. Summary of the gas phase basicities $(\mathrm{kJ} / \mathrm{mol}, 298 \mathrm{~K})$ of the $\mathrm{L}$ - $\alpha$-amino acids studied.

\begin{tabular}{|c|c|c|c|}
\hline \multirow[t]{2}{*}{ M } & \multicolumn{3}{|c|}{$\mathrm{GB}(\mathrm{kJ} / \mathrm{mol})$} \\
\hline & Equilibrium $^{\mathbf{a}}$ & Bracketing & Thermokinetic \\
\hline Gly & $852.2^{11} ; 851.1^{11} ; 856.5^{12}$ & $829-857$ & $851.1 \pm 1.9^{6}$ \\
\hline Ala & $877.9^{11} ; 864.5^{11} ; 869.3^{12}$ & $870-878$ & $865.4 \pm 0.4^{8}$ \\
\hline Pro & $899.7^{11} ; 896.8^{11} ; 911.0^{12}$ & 898-918 & $895.7 \pm 1.6^{9}$ \\
\hline Ser & $880.3^{12}$ & $864-870$ & $870.6 \pm 4.3^{7}$ \\
\hline Lys & $943.9^{12}$ & $919-951$ & $941.2 \pm 7.5^{10}$ \\
\hline His & $950.0^{12}$ & 898-951 & $941.1 \pm 5.4^{10}$ \\
\hline
\end{tabular}

a) Gas phase basicities deduced from equilibrium constant measurements.

b) Gas phase basicities deduced from bracketing experiments as adapted by Hunter\&Lias².

c) Gas phase basicities deduced by the thermokinetic method from rate constant measurements.

Table 3. Proton affinities $(\mathrm{kJ} / \mathrm{mol}, 298 \mathrm{~K})$ and protonation entropies $\left(\mathrm{J} . \mathrm{mol}^{-1} \cdot \mathrm{K}^{-1}, \mathbf{2 9 8 K}\right)$ of the $\mathrm{L}-\alpha-$ aminoacids studied.

\begin{tabular}{|c|c|c|c|c|}
\hline M & Kinetic method ${ }^{\mathbf{a}}$ & Equilibrium $^{\mathbf{b}}$ & Thermokinetic ${ }^{\mathbf{c}}$ & $\Delta_{\mathrm{P}} S^{\circ}(\mathrm{M})^{\mathbf{d}}$ \\
\hline Gly & $888.0^{15} ; 896.1^{18}$ & $882.5^{11}$ & $883.1 \pm 1.9$ & $2^{11}$ \\
\hline Ala & $\begin{array}{l}899.4^{15} ; 903.2^{18} \\
{[902]^{21}}\end{array}$ & $900.0^{11}$ & $894.5 \pm 0.4$ & $\begin{array}{l}11^{11} \\
{[0]^{20}}\end{array}$ \\
\hline Pro & $\begin{array}{l}925.8^{15}, 938.5^{16}, 944.5^{18} \\
{[926.2]^{19},[941.0]^{20}}\end{array}$ & $932.0^{11}$ & $925.9 \pm 1.6$ & $8^{11}$ \\
\hline Ser & $905.9^{15} ; 912.9^{16}$ & - & $904.5 \pm 4.3$ & $(-5)^{f}$ \\
\hline Lys & $\begin{array}{l}941.3^{15} ; 969.6^{16} ; 964.3^{18} \\
{[996]^{17}}\end{array}$ & - & $994.5 \pm 7.5$ & $\begin{array}{l}(-70)^{\mathrm{g}} \\
{[-42]^{17}}\end{array}$ \\
\hline His & $\begin{array}{l}978.5^{16} ; 966.8^{18} \\
{[988]^{17}}\end{array}$ & - & $988.4 \pm 5.4$ & $\begin{array}{l}(-50)^{\mathrm{h}} \\
{[-17]^{17}}\end{array}$ \\
\hline $\begin{array}{l}\text { a) Proton affir } \\
\text { the full entrop } \\
\text { b) Proton affir } \\
\text { c) Calculated } \\
\text { thermokinetic } \\
\text { d) Protonation } \\
\text { obtained by th } \\
\text { f) Assumed by } \\
\text { g) Assumed b } \\
\text { h) Assumed b }\end{array}$ & $\begin{array}{l}\text { es determined by the kinet } \\
\text { inalysis. } \\
\text { es deduced from equilibri } \\
\text { ng eq. } 5 \text { and the gas phase } \\
\text { ethod (Table } 2) \text { and the pr } \\
\text { itropy } \Delta_{\mathrm{p}} \mathrm{S}^{\circ}(\mathrm{M})=\mathrm{S}^{\circ}\left(\mathrm{MH}^{+}\right. \\
\text {sinetic method using the fu } \\
\text { omparison with } \mathrm{CH}_{3} \mathrm{NH}_{2}^{2} \text {. } \\
\text { omparison with } 1,5 \text {-diami } \\
\text { omparison with } 1,3 \text {-diami }\end{array}$ & $\begin{array}{l}\text { ackets, values } \\
\text { irements at var } \\
\text { d from rate con } \\
\text { indicated in co } \\
\text { led by Hunter a } \\
\text { s. }\end{array}$ & $\begin{array}{l}\text { ained by the kinet } \\
\text { is temperatures. } \\
\text { nt measurements } \\
\text { nn d. } \\
\text { Lias }{ }^{2} \text {. Into bracke }\end{array}$ & thod using \\
\hline
\end{tabular}


Table 4. Summary of the gas phase basicities $(\mathrm{kJ} / \mathrm{mol}, 298 \mathrm{~K})$ of the considered dipeptides.

\begin{tabular}{|c|c|c|}
\hline \multirow[t]{2}{*}{ M } & \multicolumn{2}{|l|}{$\mathrm{GB}(\mathrm{kJ} / \mathrm{mol})$} \\
\hline & Thermokinetic & Hunter\&Lias² \\
\hline GlyGly & $876.4 \pm 2.2$ & $882 \pm 8$ \\
\hline AlaAla & $894.5 \pm 1.2$ & $905.6^{22 \mathbf{b}}$ \\
\hline SerSer & $895.6 \pm 1.0$ & $886 \pm 3$ \\
\hline ProPro & $953.6 \pm 1.8$ & $945 \pm 6$ \\
\hline GlyAla & $888.0 \pm 1.2$ & - \\
\hline AlaGly & $891.8 \pm 0.9$ & - \\
\hline GlySer & $885.5 \pm 0.4$ & $881 \pm 3$ \\
\hline SerGly & $892.9 \pm 1.7$ & $886 \pm 3$ \\
\hline GlyHis & $976.5 \pm 4.7(58 \%)$ & \\
\hline & $955.6 \pm 3.0(42 \%)$ & $955 \pm 5^{a}$ \\
\hline HisGly & $976.5 \pm 4.7$ (63\%) & \\
\hline & $955.8 \pm 3.0(37 \%)$ & $955 \pm 5^{a}$ \\
\hline GlyLys & $956.2 \pm 3.7$ & $945 \pm 6$ \\
\hline LysGly & $971.5 \pm 2.0$ & $(946)^{\mathbf{b}}$ \\
\hline GlyPro & $906.4 \pm 4.7$ & $906 \pm 6$ \\
\hline ProGly & $925.0 \pm 5.1$ & $925 \pm 4$ \\
\hline
\end{tabular}

a) See text.

b) Erroneous value in ref. 2, see text. 
Table 5. Summary of the gas phase basicities $(\mathrm{kJ} / \mathrm{mol}, 298 \mathrm{~K})$ of the studied tripeptides and higher.

\begin{tabular}{|c|c|c|}
\hline \multirow[t]{2}{*}{ M } & \multicolumn{2}{|l|}{$\mathrm{GB}(\mathrm{kJ} / \mathrm{mol})$} \\
\hline & Thermokinetic & Hunter\&Lias² \\
\hline GlyGlyGly & $903.9 \pm 3.4$ & $916.8^{22 c}$ \\
\hline GlyGlyAla & $902.1 \pm 3.0$ & $914.8^{22 b}$ \\
\hline GlyAlaGly & $898.2 \pm 2.3$ & - \\
\hline AlaGlyGly & $900.1 \pm 2.4$ & $917.8^{22 \mathbf{b}}$ \\
\hline \multirow[t]{2}{*}{ GlyGlyPro } & $981.2 \pm 4.0(55 \%)$ & \\
\hline & $913.6 \pm 1.9(45 \%)$ & $915 \pm 4$ \\
\hline \multirow[t]{2}{*}{ GlyProGly } & $984.7 \pm 7.0(54 \%)$ & \\
\hline & $918.3 \pm 2.5(46 \%)$ & $915 \pm 4^{\mathrm{a}}$ \\
\hline \multirow[t]{2}{*}{ ProGlyGly } & $961.9 \pm 4.0(44 \%)$ & \\
\hline & $924.0 \pm 5.9(56 \%)$ & $925 \pm 4^{\mathrm{a}}$ \\
\hline GlyGlyHis & $976.1 \pm 5.0$ & $979.5^{22 b}$ \\
\hline \multirow[t]{2}{*}{ GlyHisGly } & $984.7 \pm 5.0(58 \%)$ & \\
\hline & $955.7 \pm 3.8(42 \%)$ & $955 \pm 4^{\mathrm{a}}$ \\
\hline HisGlyGly & $976.0 \pm 4.9$ & $(946)^{\mathbf{b}}$ \\
\hline GlyGlyLys & $989.1 \pm 4.1$ & $(958.6)^{\mathbf{b}}$ \\
\hline GlyLysGly & $968.9 \pm 4.3$ & - \\
\hline LysGlyGly & $987.6 \pm 4.1$ & $(958.6)^{\mathbf{b}}$ \\
\hline$(\text { Gly })_{4}$ & $922.4 \pm 3.0$ & $928^{21 c}$ \\
\hline$(\text { Gly })_{5}$ & $935.0 \pm 6.4$ & $921 \pm 26$ \\
\hline$(G l y)_{6}$ & $940.0 \pm 9.1$ & $950 \pm 17$ \\
\hline
\end{tabular}

a) See text.

b) Erroneous value in ref. 2, see text. 